\title{
Sources and export of nutrients associated with integrated multi-trophic aquaculture in Sanggou Bay, China
}

\author{
Ruihuan Li $^{1,5}$, Sumei Liu ${ }^{1,2, *}$, Jing Zhang ${ }^{3}$, Zengjie Jiang ${ }^{4}$, Jianguang Fang ${ }^{4}$ \\ ${ }^{1}$ Key Laboratory of Marine Chemistry Theory and Technology, MOE, Ocean University of China/Qingdao Collaborative \\ Innovation Center of Marine Science and Technology, Qingdao 266100, PR China \\ ${ }^{2}$ Laboratory for Marine Ecology and Environmental Science, \\ Qingdao National Laboratory for Marine Science and Technology, Qingdao, PR China \\ ${ }^{3}$ State Key Laboratory of Estuarine and Coastal Research, East China Normal University, Shanghai 200062, PR China \\ ${ }^{4}$ Carbon Sink Fisheries Laboratory, Key Laboratory of Sustainable Utilization of Marine Fisheries Resources, \\ Ministry of Agriculture, Yellow Sea Fisheries Research Institute, Chinese Academy of Fishery Sciences, 106 Nanjing Road, \\ Qingdao 266071, PR China
}

${ }^{5}$ Present address: State Key Laboratory of Tropical Oceanography, South China Sea Institute of Oceanology, Chinese Academy of Sciences, 164 West Xingang Road, Guangzhou 510301, PR China

\begin{abstract}
Field observations were made from 2012 to 2014 at an integrated multi-trophic aquaculture (IMTA) site in Sanggou Bay (SGB), China, to characterize the nutrients associated with aquaculture activities, and to assess the effects of aquaculture on nutrient cycles in the bay. Dissolved inorganic and organic nutrient levels were measured in rivers, groundwater, and SGB. Seasonal variations in nutrient concentrations were detected in the rivers, particularly enrichment of dissolved inorganic nitrogen (DIN) and silicate (DSi). Nutrient concentrations showed considerable seasonal variation, with higher and significantly different concentrations occurring in autumn than in the other seasons. The composition and distribution of nutrients were also affected by the species being cultured. Dissolved organic nitrogen and phosphorus (DON and DOP) accounted for 27 to $87 \%$ of total dissolved nitrogen and 34 to $81 \%$ of total dissolved phosphorus, respectively. Phosphorus may be a potentially limiting nutrient for phytoplankton growth in summer. Nutrient budgets were developed based on a simple steady-state box model. These showed that bivalve aquaculture was the major source of $\mathrm{PO}_{4}{ }^{3-}$ (contributing $64 \%$ of total influx) and led to increased riverine fluxes of $\mathrm{PO}_{4}{ }^{3-}$. The results indicated that substantial quantities of nitrogen and DSi accumulated in sediments or were transformed into other forms (e.g. phytoplankton cell composition or particles). Large quantities of DIN and $\mathrm{PO}_{4}{ }^{3-}$ were removed from the bay through harvesting of seaweeds and bivalves, which represented up to 64 and $81 \%$ of total outflux, respectively. The results show that aquaculture activities play the most important role in nutrient cycling in SGB.
\end{abstract}

KEY WORDS: Nutrients $\cdot$ IMTA $\cdot$ Budgets $\cdot$ Aquaculture activities $\cdot$ Sanggou Bay

\section{INTRODUCTION}

With an annual average increase of $8.7 \%$ over the past $40 \mathrm{yr}$, aquaculture is the fastest-growing food production sector in the world, and is overtaking capture fisheries as a source of food fish (Herbeck et al.

\footnotetext{
${ }^{*}$ Corresponding author: sumeiliu@ouc.edu.cn
}

2013). The rapid growth of aquaculture has given rise to a wide variety of environmental problems, including ecosystem degradation and water pollution (Neori et al. 2004). One of the largest of impacts of aquaculture effluents to local ecosystems is imbalance created in nutrient dynamics and eutrophic

() The authors 2016. Open Access under Creative Commons by Attribution Licence. Use, distribution and reproduction are unrestricted. Authors and original publication must be credited. 
conditions (Marinho-Soriano et al. 2009, Bouwman et al. 2011). In addition, excess nutrients cause stress in the cultivated organisms, with deleterious effects including smaller size, reduced production, and mass mortality (Newell 2004, Mao et al. 2006). Due to increasing concerns about the environmental impacts of aquaculture, a new method of aquaculture with a smaller ecological footprint has been developed. Integrated multi-trophic aquaculture (IMTA) has the potential to mitigate the environmental impacts of aquaculture (Buschmann et al. 2008).

IMTA is described as the cultivation of aquatic species from different trophic levels within a shared water system (Bostock et al. 2010). Such systems significantly increase the sustainability of aquaculture and recycle waste nutrients from high trophic-level species into production of lower trophic-level crops of commercial value (Troell et al. 2009). Seaweeds are used in IMTA systems for their nutrient-absorbing and sequestering properties. Nutrients excreted and egested by bivalves can be absorbed by macroalgae and recycled into valuable biomass (Newell 2004, Buschmann et al. 2008), and this amount of nutrient waste can be effectively removed from the ecosystem. In addition, a number of studies have confirmed that suspension-feeding bivalves can exert top-down control on phytoplankton (Newell \& Koch 2004, Wall et al. 2008); larger nanoplankton will be removed in comparison with smaller $(<3 \mu \mathrm{m}$ diameter) picoplankton species, thereby reducing turbidity (Newell 2004). The resulting increased light penetration can potentially enhance the production of benthic plants (Newell \& Koch 2004). If high levels of dissolved inorganic nitrogen (DIN) regenerated by bivalves are sufficient to allow the relatively slowgrowing nanoplankton to grow fast enough to overcome grazer control, primary production can be stimulated through recycling of nitrogen (Smaal et al. 2001). Some marine IMTA systems have been commercially successful at industrial scales, especially in Asia (China) (Troell et al. 2009).

China is the largest aquaculture producer in the world, with a total production of 34.1 million tons, which accounts for $62 \%$ of total global production and $51 \%$ of the global value (Yang et al. 2005, FAO 2010, Yuan et al. 2010, Yu et al. 2012). The area devoted to aquaculture increased from $11.2 \times 10^{4}$ ha in 1977 to $218 \times 10^{4}$ ha in 2012 (The People's Republic of China Ministry of Agriculture Fisheries Bureau 2013). The rapid growth of aquaculture has led to eutrophication of coastal waters (Wu et al. 2014), and to the occurrence of aquatic diseases that have resulted in major economic losses (Fei 2004); for example, in 1998, more than 10 billion Chinese Yuan (approximately US\$ 1.5 billion) were lost because of mariculture disease (Fei 2004). To improve the environmental sustainability of aquaculture and benefit the local economy, IMTA was developed in China. Sea-ranching and suspended aquaculture are the 2 main forms of IMTA in China, and the latter is used in Sanggou Bay.

Sanggou Bay (SGB) is located in northern China and has been used for aquaculture for over $30 \mathrm{yr}$ (Zhang et al. 2009). It has been estimated that more than $300 \mathrm{t}$ of inorganic nitrogen have been excreted into the bay by cultivated and fouling animals (Troell et al. 2009). Studies of core sediments also indicated that the total nitrogen (TN) content has increased in recent decades as a consequence of aquaculture activities (Song et al. 2012). Bivalves clear seston particles $>3 \mu \mathrm{m}$ in diameter from natural water and are not supplied with additional feed in the bay. The absolute and relative abundances of dinoflagellate cells in the bay are lower inside the scallop culture area than outside (Zhang et al. 2005), and the phytoplankton community has changed as a result; meanwhile, the reduction in phytoplankton biomass has a negative impact on bivalve growth (Duarte et al. 2003, Shi et al. 2011a). In addition, kelp can compete with phytoplankton for nutrients, and $80000 \mathrm{t}$ of dried kelp can be produced annually through uptake of inorganic nitrogen from the bay (Zhang et al. 2009). In pursuing high levels of productivity, SGB has been subject to a rapid growth in aquaculture, with long-line culture of kelp having expanded to areas more than $8 \mathrm{~km}$ away from the coast, where the water depth is between 20 and $30 \mathrm{~m}$ (Troell et al. 2009, Fu et al. 2013).

Much attention has been focused on the carrying capacity of shellfish and kelp mariculture (Bacher et al. 2003, Nunes et al. 2003, Shi et al. 2011a), ecology (Song et al. 2007, Hao et al. 2012), nutrient levels (Wang 2012, Zhang et al. 2012), and nutrient fluxes at the sediment-water interface (Jiang et al. 2007, Sun et al. 2010) in SGB, but the effects of aquaculture activities on nutrient cycling have not been well studied in the bay. The objective of this study was to determine the amounts and composition of dissolved nutrients in the bay and associated rivers and groundwater, to assess the sources and transportation of nutrients, to evaluate the impact of aquaculture activities on nutrient cycling, and to discriminate the importance of internal nutrient inputs vs. physical transport, based on the land-ocean interactions in the coastal zone (LOICZ) nutrient model (Gordon et al. 1996). 


\section{MATERIALS AND METHODS}

\section{Study area}

SGB (Fig. 1) is a semi-enclosed water body of approximately $144 \mathrm{~km}^{2}$ at the eastern end of Shandong Peninsula, and has an average depth of $7.5 \mathrm{~m}$ (Zhang et al. 2009). The bay is characterized by semidiurnal tides having an average tidal range of $2 \mathrm{~m}$, and is connected to the Yellow Sea through an $11.5 \mathrm{~km}$ wide channel (Mao et al. 2006, Jiang et al. 2007). It is dominated by land-ocean climate, with water temperatures ranging from 2 to $26^{\circ} \mathrm{C}$ (Kuang et al. 1996). Approximately $73.3 \%$ of annual precipitation in the area $(819.6 \mathrm{~mm})$ occurs during the wet season, from June to September. The average river discharge into the bay is $1.7-2.3 \times 10^{8} \mathrm{~m}^{3} \mathrm{yr}^{-1}$, and this carries an annual sediment load of $17.1 \times 10^{4} \mathrm{t}$.

More than $70 \%$ of the area of SGB is currently used for aquaculture (Zhang et al. 2009, 2010, Fu et al. 2013). It is one of the largest aquaculture production sites in China, and is extensively used for the culture

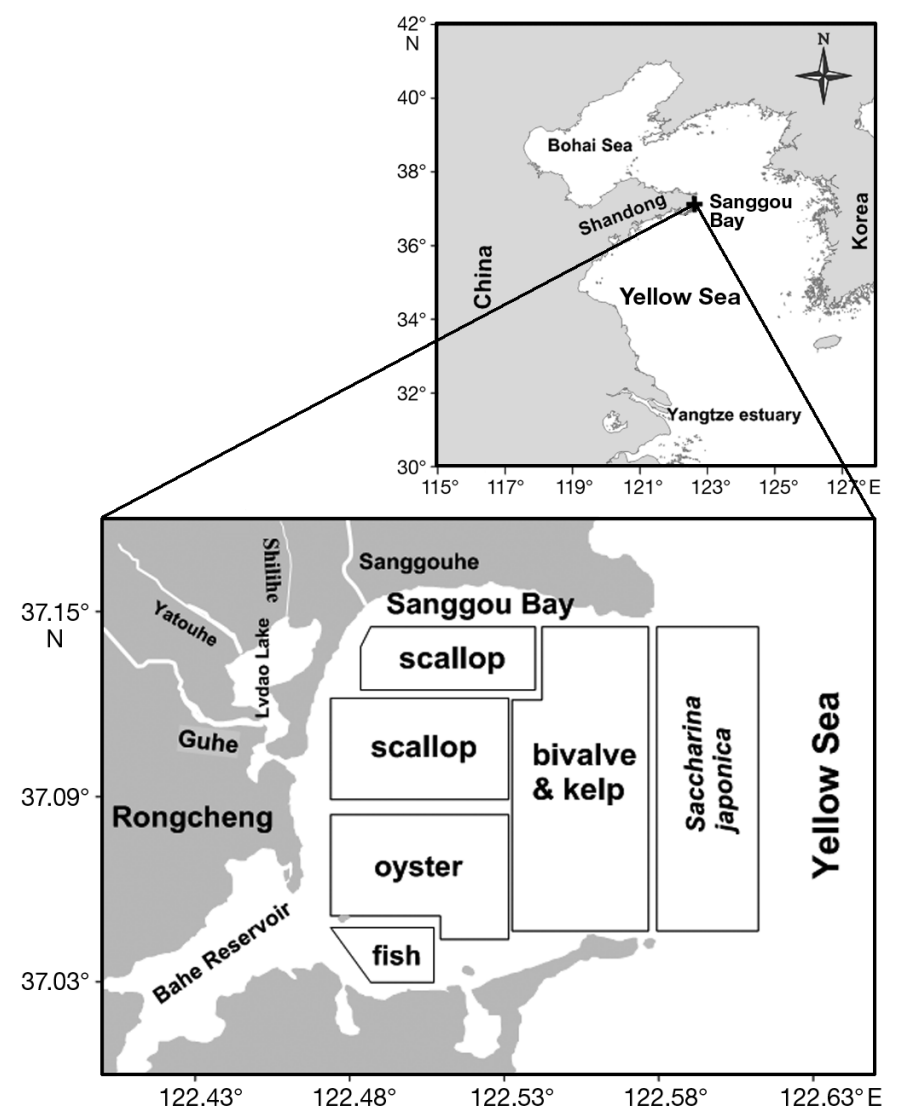

Fig. 1. Location of Sanggou Bay, China, and aquaculture activities, showing the regions of kelp (Saccharina japonica) monoculture; scallop, oyster, and fish monoculture; and multispecies aquaculture of scallops (Chlamys farreri), Pacific oyster Crassostrea gigas, and seaweeds (Saccharina japonica and Gracilaria lemaneiformis) (Zhang et al. 2009). These species are grown in both monoculture and polyculture, from suspended longlines (Fang et al. 1996a) (Fig. 1). S. japonica monoculture occurs mainly near the mouth of the bay, bivalves are mainly cultured in the western part of the bay, and kelp and bivalve polyculture occurs in the middle part of the bay (Fig. 1). The co-cultivation of abalone Haliotis discus hannai with kelp ( $S$. japonica) has also been developed, with the abalones held in lantern nets hanging vertically from the longlines. In 2012, production included approximately $84500 \mathrm{t}$ dry weight of $S$. japonica, $25410 \mathrm{t}$ wet weight of $G$. lemaneiformis, and approximately 15000 and $60000 \mathrm{t}$ wet weight of $C$. farreri and C. gigas, respectively (data from Rongcheng Fishery Technology Extension Station). The main cultured species has shifted from scallop to oyster since 1996 because of reduced scallop production as a consequence of disease (Zhang et al. 2009).

To increase production, aquaculture has expanded from the bay to the open sea since the 1990s (Fang et al. 1996a). However, the total aquaculture production of kelp has not increased (Shi et al. 2011a). This may be related to a reduced supply of nutrients resulting from a decrease in the water exchange rate, which has been a consequence of reduced circulation because of the increase in aquaculture activities (Fang et al. 1996b). The hydrodynamic conditions have changed significantly because of the presence of suspended aquaculture (Shi et al. 2011a). Current speeds can be reduced by aquaculture facilities including rafts, and ropes impose drag (Grant \& Bacher 2001, Duarte et al. 2003). The renewal of suspended particles for bivalve culture and nutrient regeneration for kelp have also been reduced (Grant \& Bacher 2001, Duarte et al. 2003). Compared with the period of farming activities up to 1983, tidal currents had decreased by $50 \%$ by 1994 because of large-scale cultivation (Zhao et al. 1996). Based on a 2-dimensional model, Grant \& Bacher (2001) estimated a reduction of $41 \%$ in the water exchange rate in SGB because of increased bottom friction with expansion of intensive suspended aquaculture. The vertical current has also changed because of suspended aquaculture (Fan \& Wei 2010).

\section{Sample collection}

Sampling took place during 31 May to 4 June 2012 (early summer), 20 September to 2 October 
2012 (early autumn), 22 to 25 April 2013 (spring), 21 to 25 July 2013 (summer), 16 to 17 October 2013 (autumn), and 15 to 17 January 2014 (winter) (Fig. 2). Two anchor stations for monitoring over complete tidal cycles of $25 \mathrm{~h}$ were established, one in April 2013 in the northern mouth of the bay (D1), and the other in October 2013 in the southern mouth (D2) (Fig. 2), respectively. At each station, surface water samples were collected by submersing a 11 acid-cleaned polyethylene bottle from a boat, and bottom water samples were collected using a 51 polymethyl methacrylate water sampler. River water samples were collected from the river edge in $0.5 \mathrm{l}$ acid-cleaned polyethylene bottles, and groundwater was collected from wells around the bay (Fig. 2).

Water temperature and salinity were measured in situ using a WTW MultiLine F/Set3 multi-parameter
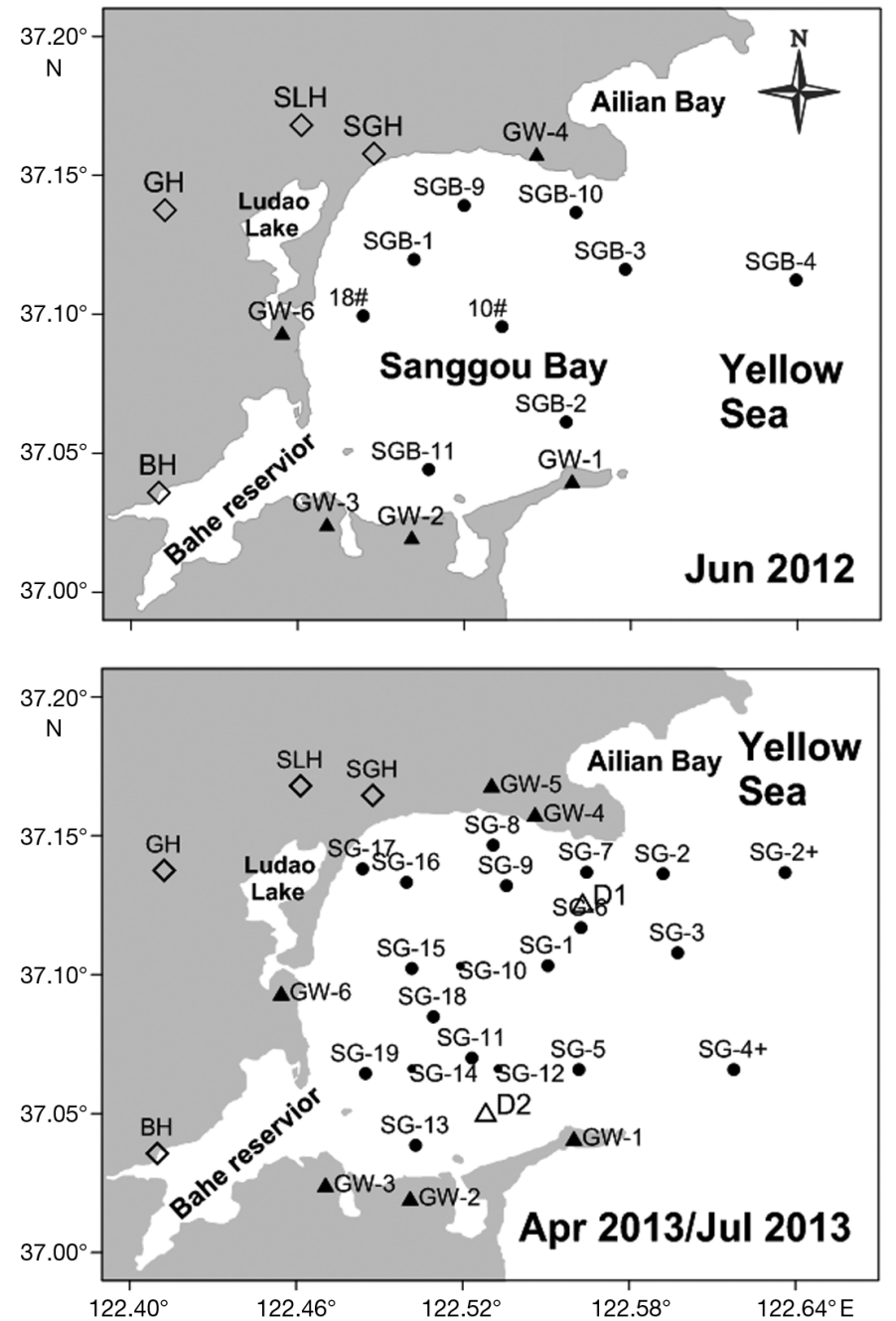

probe. Each water sample was immediately filtered through a $0.45 \mu \mathrm{m}$ pore size cellulose acetate filters (pre-cleaned with hydrochloric acid, $\mathrm{pH}=2$ ) into a polyethylene bottle that had previously been rinsed 3 times with some of the filtered water sample. The filtrates were fixed by the addition of saturated $\mathrm{HgCl}_{2}$ solution (Liu et al. 2005), and the filters were dried at $45^{\circ} \mathrm{C}$ and weighed to determine the mass of suspended particulate matter (SPM).

\section{Chemical analysis}

Dissolved nutrient concentrations were measured in the laboratory using an Auto Analyzer 3 (Seal Analytical). Total dissolved nitrogen (TDN) and total dissolved phosphorus (TDP) were measured according to the methods of Grasshoff et al. (1999). The DIN
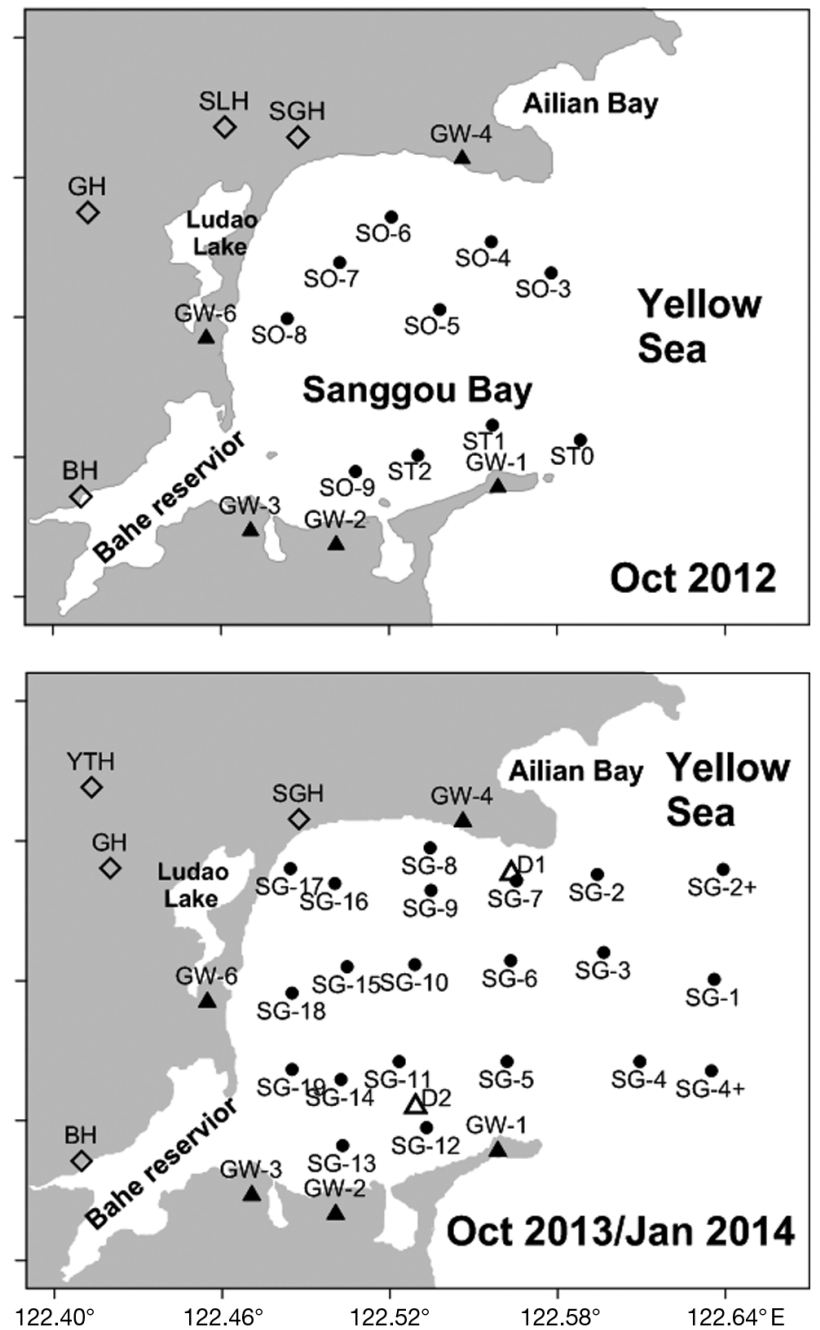

Fig. 2. Sampling stations in Sanggou Bay for the cruises during 2012 to 2014. $(\diamond)$ River stations; $(\boldsymbol{\Delta})$ groundwater stations (BH: Bahe; GH: Guhe; SLH: Shilihe; SGH: Sanggouhe; YTH: Yatouhe); $(\bullet)$ bay stations; $(\Delta)$ anchor stations 
concentration was determined as the sum of the $\mathrm{NO}_{3}{ }^{-}, \mathrm{NO}_{2}{ }^{-}$, and $\mathrm{NH}_{4}{ }^{+}$concentrations. The concentrations of dissolved organic nitrogen (DON) and dissolved organic phosphorus (DOP) were estimated by subtracting DIN from TDN and $\mathrm{PO}_{4}{ }^{3-}$ from TDP, respectively. The analytical precision of $\mathrm{NO}_{3}{ }^{-}, \mathrm{NO}_{2}{ }^{-}$, $\mathrm{NH}_{4}{ }^{+}, \mathrm{PO}_{4}{ }^{3-}$, dissolved silicate (DSi), TDN, and TDP was $<5 \%$.

\section{Statistical analysis}

Statistical analyses were performed using the software SPSS 20.0 by IBM. One-way ANOVAs were used to analyze the individual effects of seasons and particular cultivation area on variations in SPM, and 2-way ANOVAs were used to analyze the combined effects of seasons and cultivation area on variations in SPM. Two-way ANOVAs were also used to analyze the effects of surface/bottom and seasons on variations in nutrient concentrations. Based on a posteriori homogeneity tests, Tukey's HSD or Tamhane's T2 comparisons were applied to assess the statistical significance of differences $(p<0.05)$ following ANOVA.

\section{Nutrient budgets}

Dissolved nutrient budgets for the study system were constructed based on the LOICZ box model (Gordon et al. 1996). This model has been widely used to construct nutrient budgets defining the internal biogeochemical processes and external nutrient inputs of estuarine and coastal ecosystems (Savchuk 2005, Liu et al. 2009). For our model, we assumed that the study system was in a steady state, and the bay was treated as a single well-mixed box. The water mass balance, salinity balance, and the nonconservative fluxes of nutrient elements based on nutrient concentrations and water budgets were estimated according to Eqs. (1) to (3), respectively:

$$
\begin{gathered}
V_{\mathrm{R}}=V_{\text {in }}-V_{\text {out }}=-V_{\mathrm{Q}}-V_{\mathrm{P}}-V_{\mathrm{G}}-V_{\mathrm{W}}+V_{\mathrm{E}} \\
V_{\mathrm{X}}\left(S_{1}-S_{2}\right)=S_{\mathrm{R}} V_{\mathrm{R}}
\end{gathered}
$$

$\Delta Y=$ outflux - influx $=V_{\mathrm{R}} C_{\mathrm{R}}+V_{\mathrm{X}} C_{\mathrm{X}}-V_{\mathrm{Q}} C_{\mathrm{Q}}-V_{\mathrm{P}} C_{\mathrm{P}}$ $-V_{\mathrm{G}} C_{\mathrm{G}}-V_{\mathrm{W}} C_{\mathrm{W}}$

where $V_{\mathrm{R}}$ is the residual flow, and $V_{\mathrm{Q}}, V_{\mathrm{P}}, V_{\mathrm{G}}, V_{\mathrm{W}}, V_{\mathrm{E}}$, $V_{\text {in, }} V_{\text {out }}, V_{\mathrm{X}}$, and $\Delta Y$ are the river discharge, precipitation, groundwater, wastewater, evaporation, inflow of water to the system of interest, outflow of water from the system of interest, the mixing flow between the 2 systems and nonconservative flux of nutrients, respectively. The volume of aquaculture effluent discharged directly into the system of interest was not considered, as the data were limited. We assumed that the salinity of fresh water $\left(V_{\mathrm{Q}}, V_{\mathrm{P}}\right.$, and $\left.V_{\mathrm{E}}\right)$ was 0 . In Eq. (2), $S_{\mathrm{R}}=\left(S_{1}+S_{2}\right) / 2$, where $S_{1}$ and $S_{2}$ are the average salinity of the system of interest and the adjacent system, respectively. The total water exchange time $(\tau)$ of the system of interest was estimated from the ratio of $V_{\mathrm{S}}$ to $\left(V_{\mathrm{R}}+V_{\mathrm{X}}\right)$, where $V_{\mathrm{S}}$ is the volume of the system. In Eq. (3), $C_{\mathrm{Q}}, C_{\mathrm{P}}, C_{\mathrm{G}}, C_{\mathrm{W}}$, $C_{\mathrm{R}}$, and $C_{\mathrm{X}}$ are the average concentrations of nutrients in the river discharge, the precipitation, groundwater, wastewater, the residual flow, and the mixing flow, respectively. $C_{\mathrm{R}}$ and $C_{\mathrm{X}}$ equate to $\left(C_{1}+C_{2}\right) / 2$ and $\left(C_{1}-C_{2}\right)$, respectively. $C_{1}$ and $C_{2}$ are the average concentrations of nutrients in the system of interest and the adjacent system, respectively. Outflux and influx are the total nutrient flux out of and into the system of interest, respectively. A negative or positive sign for $\Delta Y$ indicates that the system of interest was a sink or a source, respectively.

\section{RESULTS}

\section{Hydrographical chacteristics}

The surface water temperature (Table 1) reflected the seasonality of this temperate system. The surface water temperature decreased from the mouth to the

Table 1. Seasonal variations in temperature, salinity, and suspended particulate matter (SPM) in Sanggou Bay, China, during the study. Mean values are given in parentheses

\begin{tabular}{|lcccccc}
\hline \multirow{2}{*}{ Season } & \multicolumn{2}{c}{ Temperature $\left({ }^{\circ} \mathrm{C}\right)$} & \multicolumn{2}{c}{ Salinity } & \multicolumn{2}{c}{ SPM $\left(\mathrm{mg} \mathrm{l}^{-1}\right)$} \\
& Surface & Bottom & Surface & Bottom & \multicolumn{2}{c}{ Surface } \\
\hline Spring & $6.00-9.60(7.60)$ & $6.10-9.90(7.80)$ & $30.2-31.3(30.8)$ & $30.1-31.4(30.7)$ & $3.91-31.9(13.6)$ & $3.59-40.5(14.9)$ \\
Summer & $13.3-25.9(20.0)$ & $13.5-20.6(17.0)$ & $28.2-30.8(30.0)$ & $30.2-30.7(30.4)$ & $3.78-26.4(13.9)$ & $5.61-92.0(37.6)$ \\
Autumn & $17.7-25.0(20.1)$ & $16.6-23.3(19.3)$ & $29.1-30.0(29.6)$ & $29.3-29.9(29.5)$ & $5.75-29.3(15.5)$ & $11.9-67.8(27.4)$ \\
Winter & $1.80-5.70(3.50)$ & $0.90-5.30(3.15)$ & $29.2-30.6(30.0)$ & $29.2-30.4(29.9)$ & $2.27-54.0(15.8)$ & $3.04-54.7(13.5)$ \\
& & & & & & \\
\hline
\end{tabular}


west of the bay in spring and summer, but increased in this direction in autumn and winter. The horizontal distribution of temperature in the near-bottom layer was similar to that in surface water, but the temperatures were generally lower. The salinity of both surface and bottom water gradually increased from the west of the bay to mouth, except in winter. The salinity was lowest in autumn (Table 1).

The SPM concentrations varied considerably among seasons and cultivation areas, as evidenced by the large ranges shown in Table 1 and Fig. 3. The average concentration of SPM showed minor differences between surface and bottom waters in spring and winter, but was significantly less in surface water than in the bottom layer in both summer and autumn between different cultivation areas, especially those involving oyster and scallop monoculture (Fig. 3). A 1-way ANOVA indicated very significant differences in SPM concentration in bottom water of the bay in different seasons $(p<0.05)$. The subsequent post hoc Tamhane's T2 test showed that the concentrations of SPM in bottom water in summer and autumn differed significantly from those in spring and winter. In addition, a 1-way ANOVA indicated highly significant differences between different cultivation areas $(\mathrm{p}<$
0.05). The subsequent post hoc Tamhane's T2 test showed that the values of SPM in both bottom and surface waters in the fish, oyster, and scallop cultivation areas differed significantly from those in the kelp, offshore, and bivalve and kelp areas.

\section{Nutrients in rivers}

Nutrient concentrations in rivers adjacent to SGB varied greatly during the study period (Table 2 ). The rivers were generally enriched with DIN relative to $\mathrm{PO}_{4}{ }^{3-}$ (Table 2). The DIN was dominated by $\mathrm{NO}_{3}{ }^{-}$, which accounted for 73 to $98 \%$ of DIN among all seasons. The $\mathrm{NO}_{2}{ }^{-}$concentrations in rivers were generally $>2 \mu \mathrm{M}$ except Bahe river $(0.14-1.13 \mu \mathrm{M}$; Table 2). The $\mathrm{PO}_{4}{ }^{3-}$ concentration ranged from 0.08 to $6.02 \mu \mathrm{M}$ in the rivers, with an annual average of $1.45 \mu \mathrm{M}$. Seasonal variation of $\mathrm{PO}_{4}{ }^{3-}$ in the Bahe river was similar to that in the Guhe river, and the $\mathrm{PO}_{4}{ }^{3-}$ concentrations in the Bahe and Guhe rivers were lower than in the Shilihe and Sanggouhe rivers (Table 2). The DSi concentrations were high in our study rivers (average $182 \mu \mathrm{M}$; Table 2), indicating a high weathering rate associated with rivers adjacent
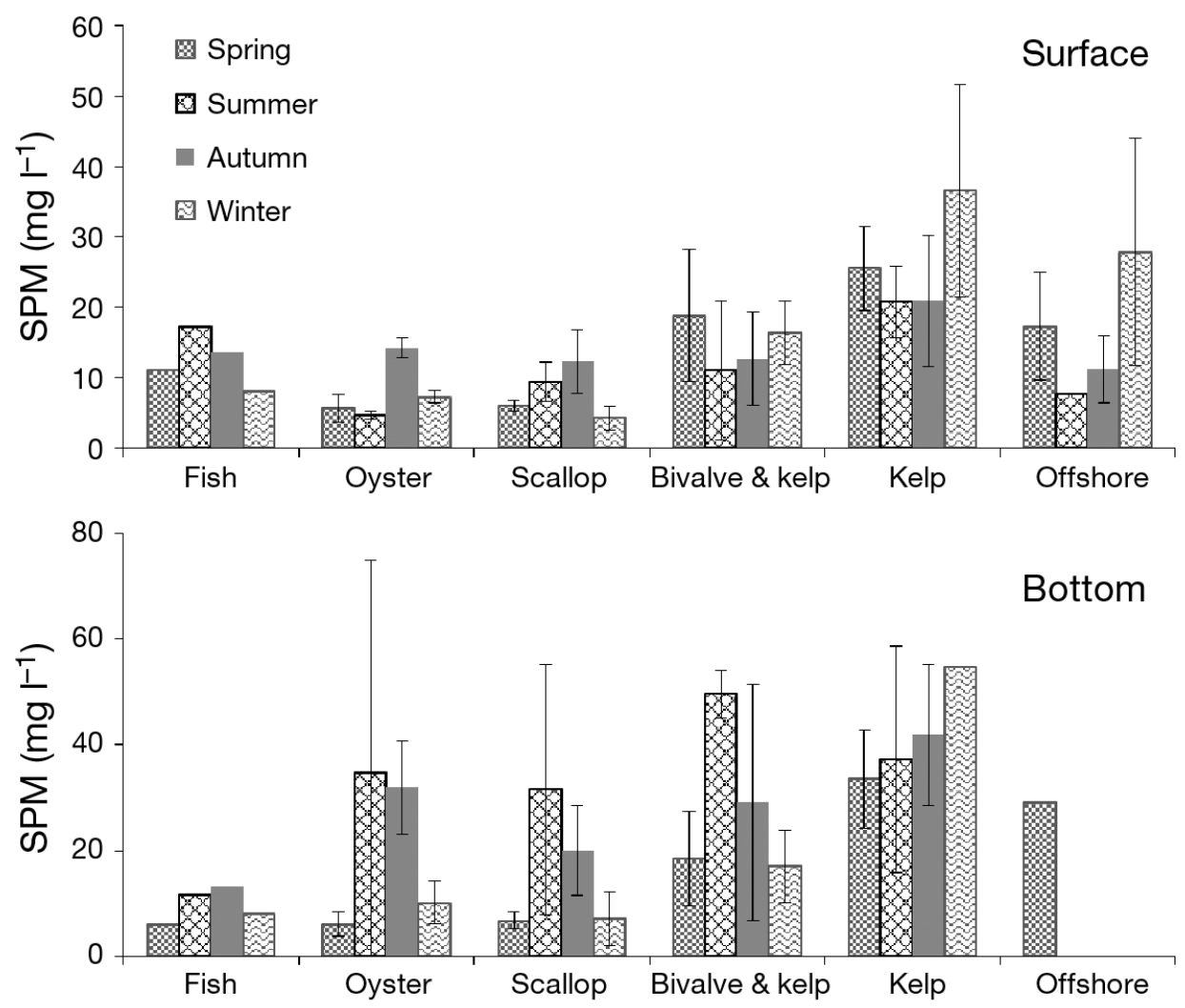

Fig. 3. Suspended particulate matter (SPM) concentrations $\left(\mathrm{mg} \mathrm{l}^{-1}\right.$; mean $\left.\pm \mathrm{SD}\right)$ in various cultivation areas in different seasons during the study periods 
Table 2. Nutrient concentrations $(\mu \mathrm{M})$ and molar ratios in surface water in rivers adjacent to Sanggou Bay, China, in different seasons during the study. DSi: dissolved silicate. Dates are given as year-month

\begin{tabular}{|lccccccc|}
\hline River & $\mathrm{NH}_{4}{ }^{+}$ & $\mathrm{NO}_{2}{ }^{-}$ & $\mathrm{NO}_{3}{ }^{-}$ & $\mathrm{PO}_{4}{ }^{3-}$ & $\mathrm{DSi}$ & $\mathrm{N}: \mathrm{P}$ & $\mathrm{Si}: \mathrm{N}$ \\
\hline Bahe & & & & & & & \\
$2012-06$ & 2.53 & 0.15 & 0.48 & 0.17 & 29.0 & 18 & 9.0 \\
$2012-09$ & 0.65 & 0.04 & 0.25 & 0.17 & 164 & 5.5 & 176 \\
$2013-04$ & 2.91 & 0.32 & 28.9 & 2.23 & 47.9 & 14 & 0.4 \\
$2013-07$ & 0.65 & 1.13 & 88.6 & 0.32 & 90.4 & 21 & 1.0 \\
$2013-10$ & 1.41 & 0.15 & 10.5 & 0.56 & 246 & 21 & 20 \\
$2014-01$ & 1.68 & 0.12 & 18.5 & 1.78 & 142 & 11 & 7.0 \\
Guhe & & & & & & & \\
$2012-06$ & 36.3 & 17.5 & 309 & 0.19 & 72.3 & 1905 & 0.2 \\
$2012-09$ & 9.86 & 10.4 & 530 & 0.08 & 102 & 7157 & 0.2 \\
$2013-04$ & 22.5 & 5.18 & 288 & 1.80 & 55.6 & 175 & 0.2 \\
$2013-07$ & 2.56 & 7.60 & 590 & 0.16 & 208 & 122 & 0.3 \\
$2013-10$ & 12.6 & 6.40 & 240 & - & 143 & - & 0.6 \\
$2014-01$ & 5.71 & 3.05 & 455 & 0.50 & 130 & 927 & 0.3 \\
Shilihe & & & & & & & \\
$2012-06$ & 103 & 4.38 & 283 & 3.23 & 364 & 121 & 0.9 \\
$2012-09$ & 17.8 & 6.70 & 600 & 0.22 & 282 & 2821 & 0.5 \\
$2013-04$ & 93.0 & 17.0 & 503 & 2.89 & 243 & 212 & 0.4 \\
$2013-07$ & 30.3 & 10.2 & 199 & 3.60 & 199 & 63 & 0.3 \\
Sanggouhe & & & & & & \\
$2012-06$ & 15.4 & 2.26 & 169 & 0.12 & 172 & 1505 & 0.9 \\
$2012-09$ & 4.00 & 17.5 & 508 & 2.60 & 182 & 204 & 0.3 \\
$2013-04$ & 8.23 & 10.2 & 351 & 1.44 & 166 & 256 & 0.5 \\
$2013-07$ & 25.0 & 16.6 & 382 & 6.02 & 382 & 106 & 0.4 \\
$2013-10$ & 2.73 & 4.40 & 362 & - & 318 & - & 0.9 \\
$2014-01$ & 7.25 & 5.65 & 569 & 2.00 & 236 & 291 & 0.4 \\
Yatouhe & & & & & & & \\
$2013-10$ & 4.68 & 3.20 & 420 & - & 189 & - & - \\
$2014-01$ & 6.50 & 4.36 & 687 & 0.36 & 211 & - & - \\
\hline
\end{tabular}

to the SGB. Except for Bahe river, the DIN:PO ${ }_{4}^{3-}$ molar ratios in the rivers were significantly higher than the Redfield ratio (Table 2), indicating that phytoplankton might be limited by phosphorus despite high $\mathrm{NO}_{3}{ }^{-}$values, especially in summer in the Bahe and Guhe rivers. The high concentrations of DIN led to DSi:DIN ratios that were less than or approached a value of 1 .

\section{Spatial and temporal variations of nutrients in SGB}

The concentrations of dissolved inorganic nutrients decreased gradually from offshore to the inner part of SGB in spring (April 2013; Fig. 4a), while the DON and DOP concentrations showed the opposite horizontal distribution (Fig. 4a). The concentrations of $\mathrm{NO}_{3}{ }^{-}$accounted for $53-92 \%$ and $56-89 \%$ of the DIN in surface and near-bottom layers, respectively. DON contributed $27-46 \%$ of TDN in surface water outside the bay, where kelp monoculture occurs, and ac- counted for $46-87 \%$ of TDN inside of the bay. DON represented $40-84 \%$ of TDN in the near-bottom layer. For phosphorus compounds, $\mathrm{PO}_{4}{ }^{3-}$ and DOP accounted for approximately 66 and $34 \%$ of TDP in the bay, respectively. The molar ratios of DIN:PO ${ }_{4}{ }^{3-}$ ranged from 7.8 to 31 (average $19 \pm 7.9 \mathrm{SD}$ ) in surface water, and from 9.4 to 69 in the near-bottom layer, respectively. The average DSi:DIN ratio was higher than the Redfield ratio in both surface $(1.3 \pm 0.8)$ and bottom $(1.2 \pm 0.6)$ waters. Studies of nutrient uptake kinetics have shown that the threshold values for phytoplankton growth are $1.0 \mu \mathrm{M}$ DIN and $0.1 \mu \mathrm{M}$ $\mathrm{PO}_{4}{ }^{3-}$ (Justi et al. 1995). In the western part of the bay, DIP concentrations were lower than the threshold values for phytoplankton growth (Fig. 4a). This suggests that phosphorus may be the most limiting element for phytoplankton growth in the following season.

During June 2012 (Fig. 4b), the levels of dissolved inorganic nutrients were lower than those in spring (Fig. 4a). The $\mathrm{NO}_{3}{ }^{-}, \mathrm{NO}_{2}{ }^{-}$, and $\mathrm{NH}_{4}{ }^{+}$concentrations decreased gradually from offshore to the inner part of the bay, while $\mathrm{PO}_{4}{ }^{3-}$ and DSi concentrations showed the opposite horizontal distribution. With respect to nitrogen compounds, $\mathrm{NO}_{3}{ }^{-}$comprised $24-78 \%$ of DIN in surface water and $34-72 \%$ in bottom water. Surface water was depleted in $\mathrm{PO}_{4}{ }^{3-}(0.03-0.17 \mu \mathrm{M})$, which led to the DIN: $\mathrm{PO}_{4}{ }^{3-}$ ratios being significantly higher than the Redfield ratio. The DIN:DSi molar ratios ranged from 0.4 to 3.2 (average $1.6 \pm 0.7$ ). In July 2013, nutrient concentrations increased significantly from the mouth of the bay to the inner part (Fig. 4c), and were higher in the near-bottom layer than in surface water. The DIN was dominated by $\mathrm{NH}_{4}{ }^{+}$, which contributed 32-89\% (mean 62\%) and $32-69 \%$ (mean $52 \%$ ) to DIN in surface water and the near-bottom layer, respectively. DON comprised $57-88 \%$ of the TDN in the entire bay, and DOP accounted for $34-75 \%$ and $46-81 \%$ of the TDP in surface water and the near-bottom layer, respectively. The molar ratios of DIN: $\mathrm{PO}_{4}{ }^{3-}$ were higher than the Redfield ratio in surface water, and the DSi:DIN ratios were higher than or comparable to the Redfield ratio. The $\mathrm{PO}_{4}{ }^{3-}$ concentrations in surface water at $70 \%$ of the stations in June 2012 (Fig. 4b), and in the southeastern part of the bay in July 2013 (Fig. 4c), were lower than the threshold values. This suggested that phytoplankton growth might be limited by P in summer. In the western part of the bay (the main area for bivalve culture) the DIN concentrations were lower than or comparable to the threshold values, suggesting that $\mathrm{N}$ might be potentially limiting for phytoplankton growth in this part of the bay. 


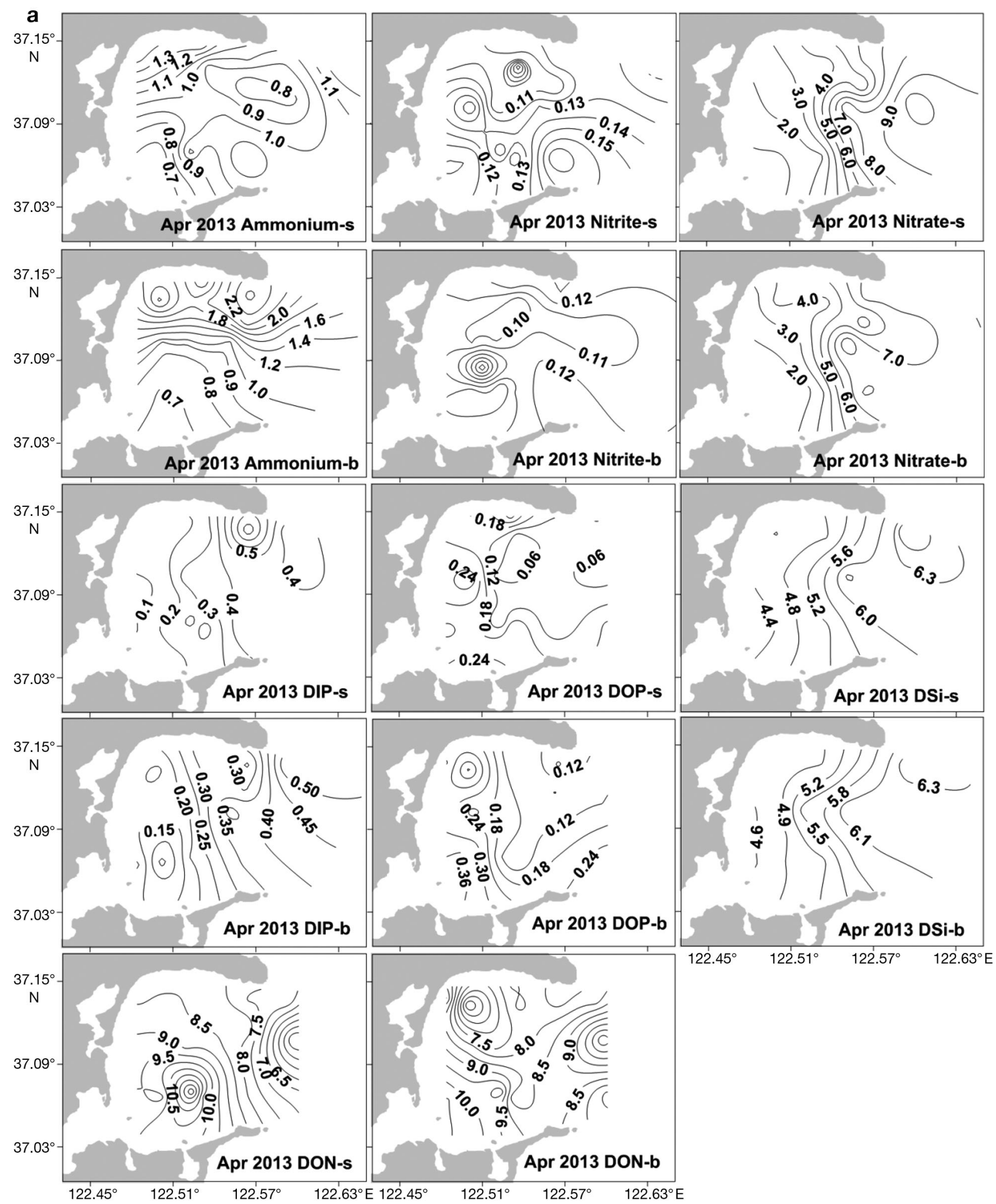

Fig. 4. Horizontal distributions of nutrients $(\mu \mathrm{M})$ in Sanggou Bay: (a) April 2013; (b) June 2012; (c) July 2013; (d) October 2012; (e) October 2013; (f) January 2014. DIP (DOP): dissolved inorganic (organic) phosphorus, DSi: dissolved silicate, DON: dissolved organic nitrogen. s: surface; b: bottom 


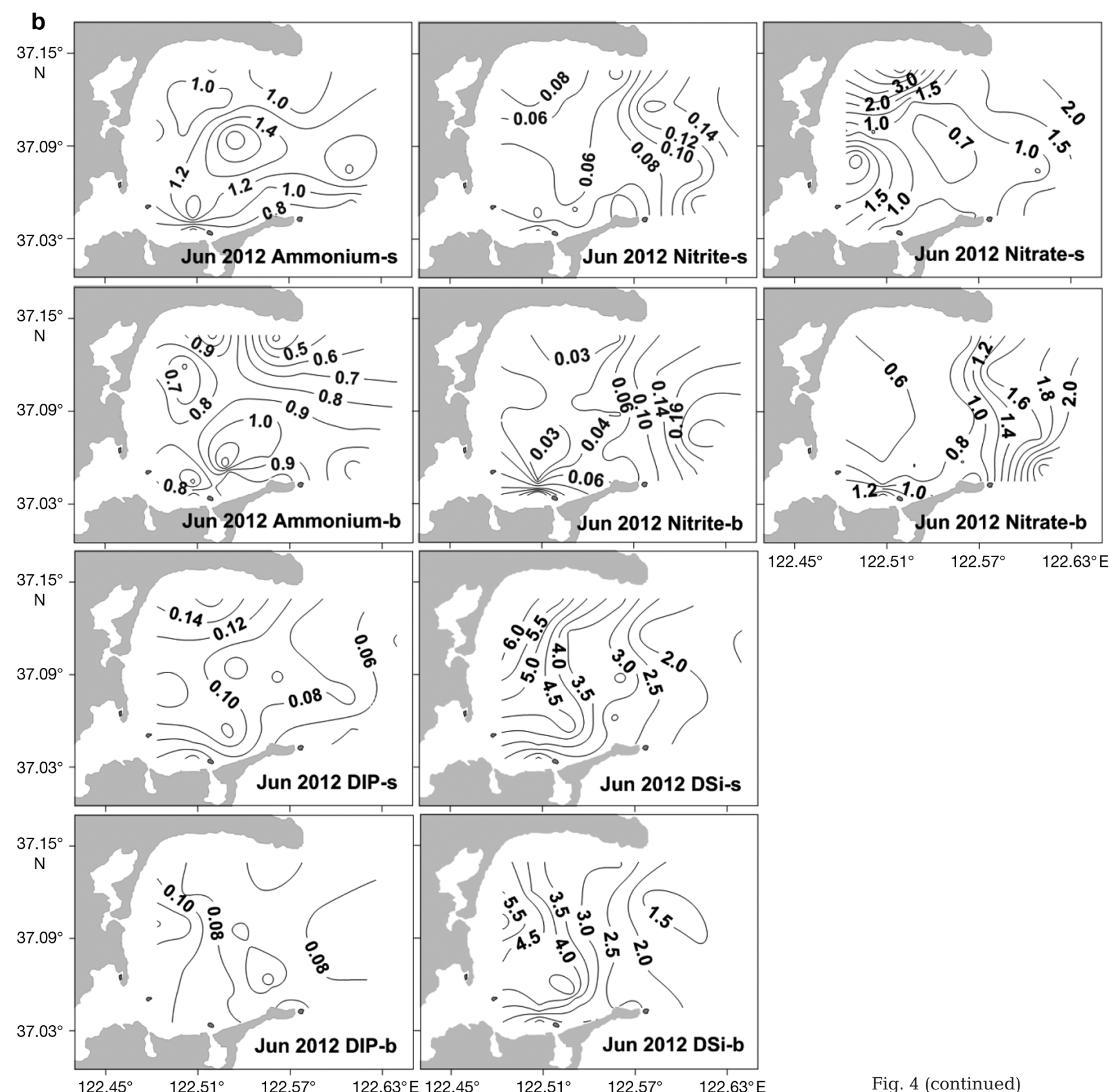

During the September-October 2012 study period, $\mathrm{NO}_{3}{ }^{-}$and $\mathrm{NH}_{4}{ }^{+}$concentrations decreased from south to north in the bay; $\mathrm{NO}_{2}{ }^{-}, \mathrm{DSi}$, and DOP increased gradually from west to east, and the $\mathrm{PO}_{4}{ }^{3-}$ concentration increased from northeast to southwest (Fig. 4d). Throughout the entire bay, $\mathrm{NO}_{3}{ }^{-}$comprised 52-86\% of DIN, and $\mathrm{NH}_{4}{ }^{+}$comprised 6-38\%. In October 2013, the $\mathrm{NO}_{3}{ }^{-}, \mathrm{NO}_{2}^{-}$, DON, DIP, and DSi concentrations decreased from the mouth to the southwestern part of the bay (Fig. 4e). Throughout the entire bay, $\mathrm{NO}_{3}{ }^{-}$accounted for $55-84 \%$ of DIN. DON comprised
$27-48 \%$ of TDN inside the bay, and $51-61 \%$ in the kelp monoculture area. DOP contributed to $12-36 \%$ and $16-50 \%$ of TDP in surface water and the bottom layer, respectively. In autumn in both 2012 and 2013, the average $\mathrm{DIN}: \mathrm{PO}_{4}{ }^{3-}$ ratios were higher than the Redfield ratio, while the DSi:DIN ratios in the water column were comparable to the Redfield ratio.

In winter, the horizontal distribution of nutrients was similar to that in spring (except for the $\mathrm{NO}_{2}{ }^{-}$and $\mathrm{NH}_{4}{ }^{+}$concentrations), with higher concentrations in the near-bottom layer than in surface water (Fig. 4f). 


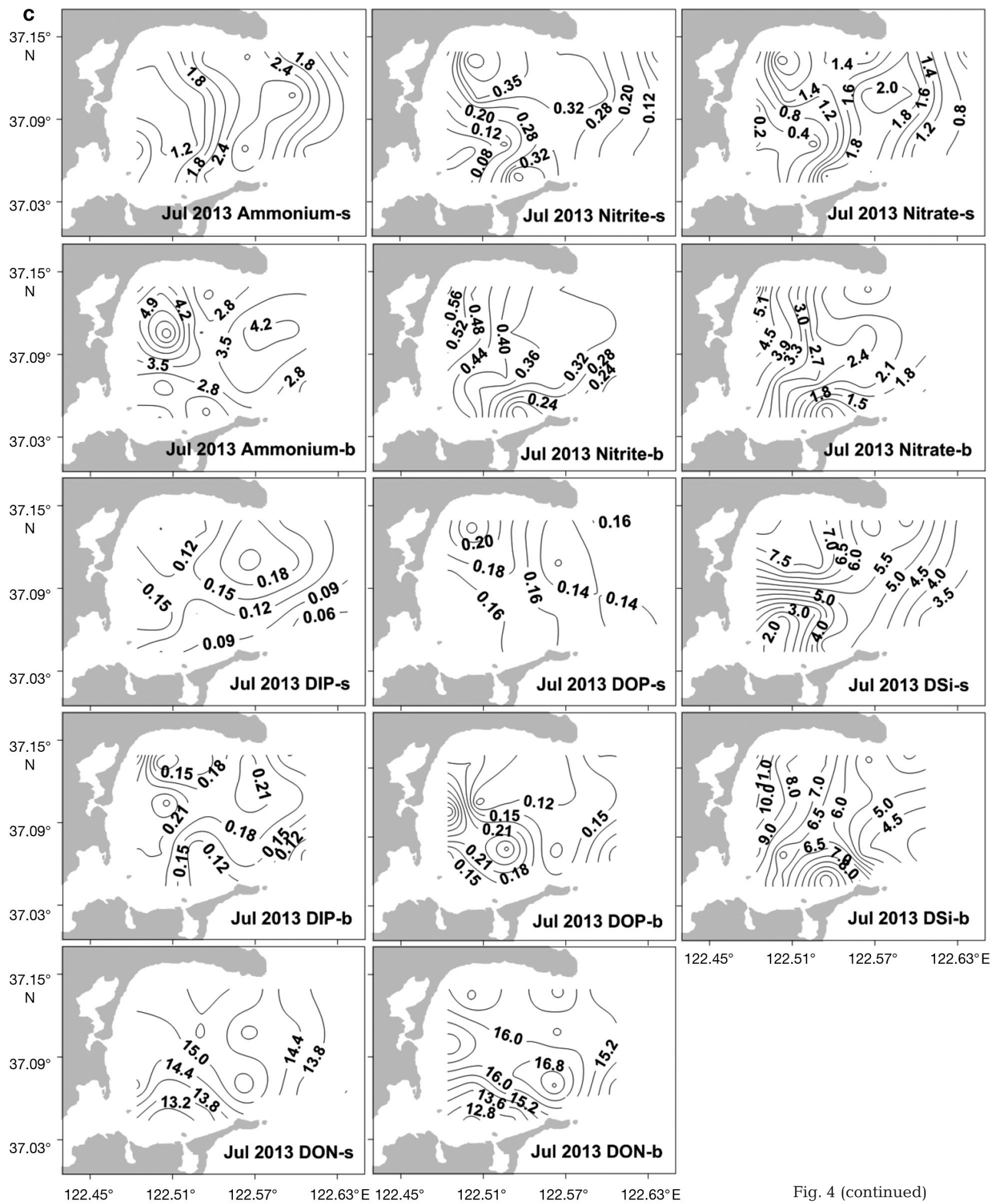




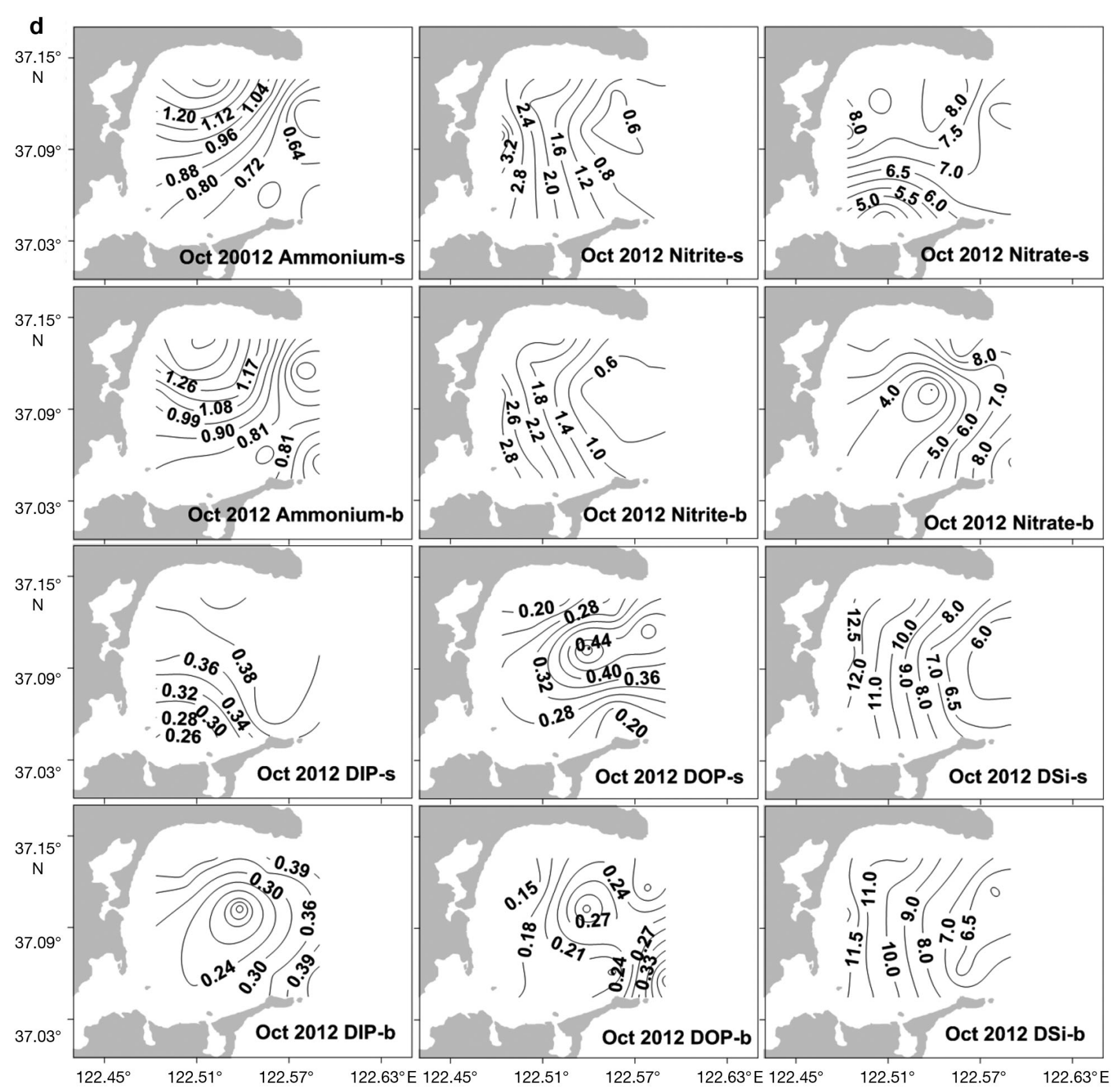

Fig. 4 (continued)

In the entire bay, $\mathrm{NO}_{3}{ }^{-}$accounted for $66-92 \%$ of DIN. DON was the dominant species of TDN, which represented $53-81 \%$ of TDN in the water column, and DOP represented $35-67 \%$ of TDP. The molar ratios of DIN:PO ${ }_{4}{ }^{3-}$ ranged from 20 to 62 and 17 to 46 in surface and bottom waters, respectively. The average DSi:DIN ratio in surface and bottom waters was comparable and significantly lower than the Redfield ratio. The results suggest that phosphorus may be a limiting element for phytoplankton growth in winter.
Seasonality in nutrient concentrations was evident in SGB (Figs. 4 \& 5). At all sites, the $\mathrm{NO}_{3}{ }^{-}, \mathrm{PO}_{4}{ }^{3-}$, and DSi concentrations were significantly higher in autumn than in the other seasons. The average $\mathrm{NO}_{3}{ }^{-}$ concentrations in surface $(9.44 \pm 4.00 \mu \mathrm{M})$ and bottom $(9.72 \pm 4.48 \mu \mathrm{M})$ waters in autumn exceeded those in summer by factors of 7.4 and 5.3, respectively. DIN was dominated by $\mathrm{NO}_{3}{ }^{-}$, except in summer. The DON concentrations in winter $(16.0 \pm 1.67 \mu \mathrm{M})$ were comparable to those in summer, and were signifi- 


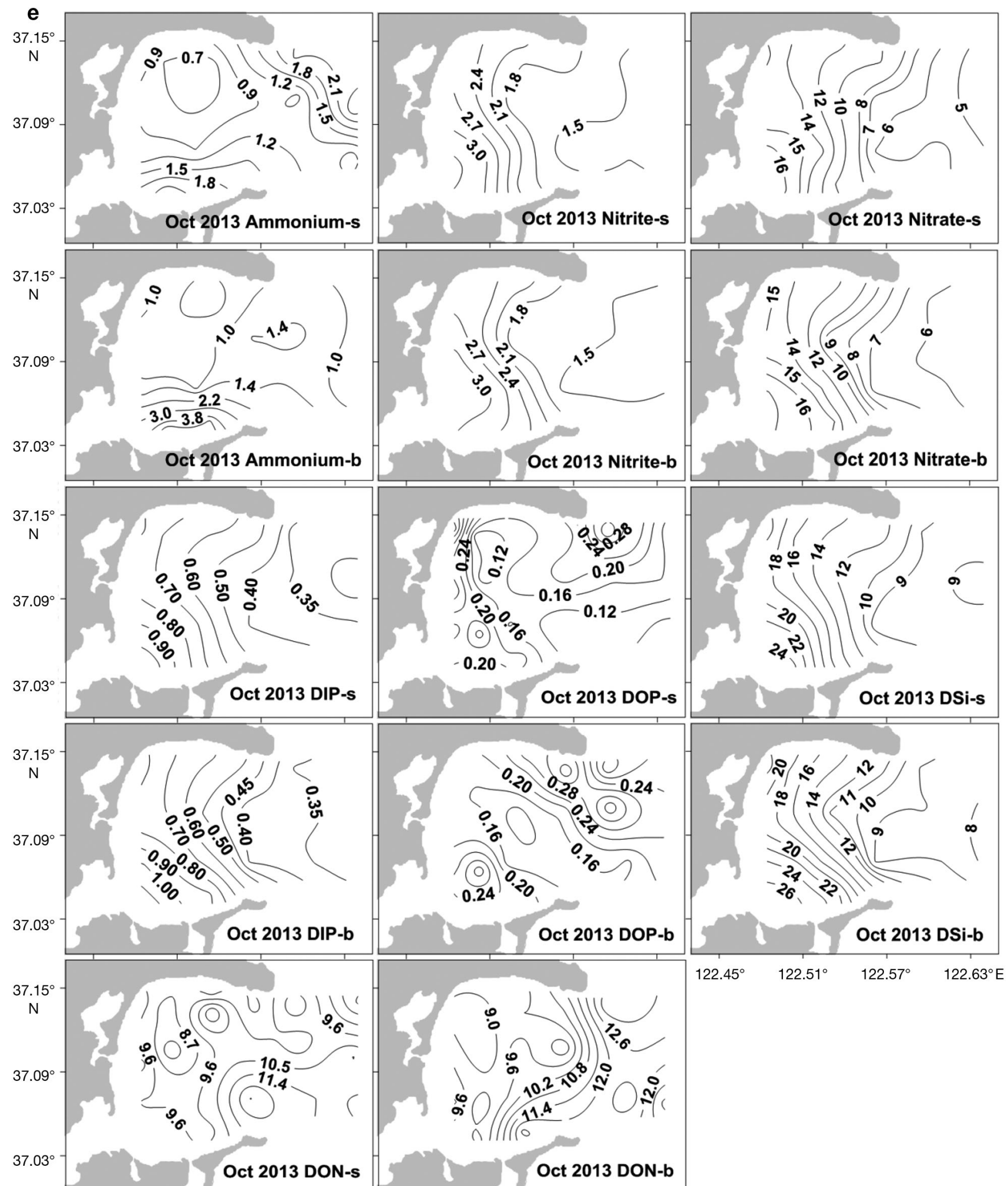

Fig. 4 (continued) 


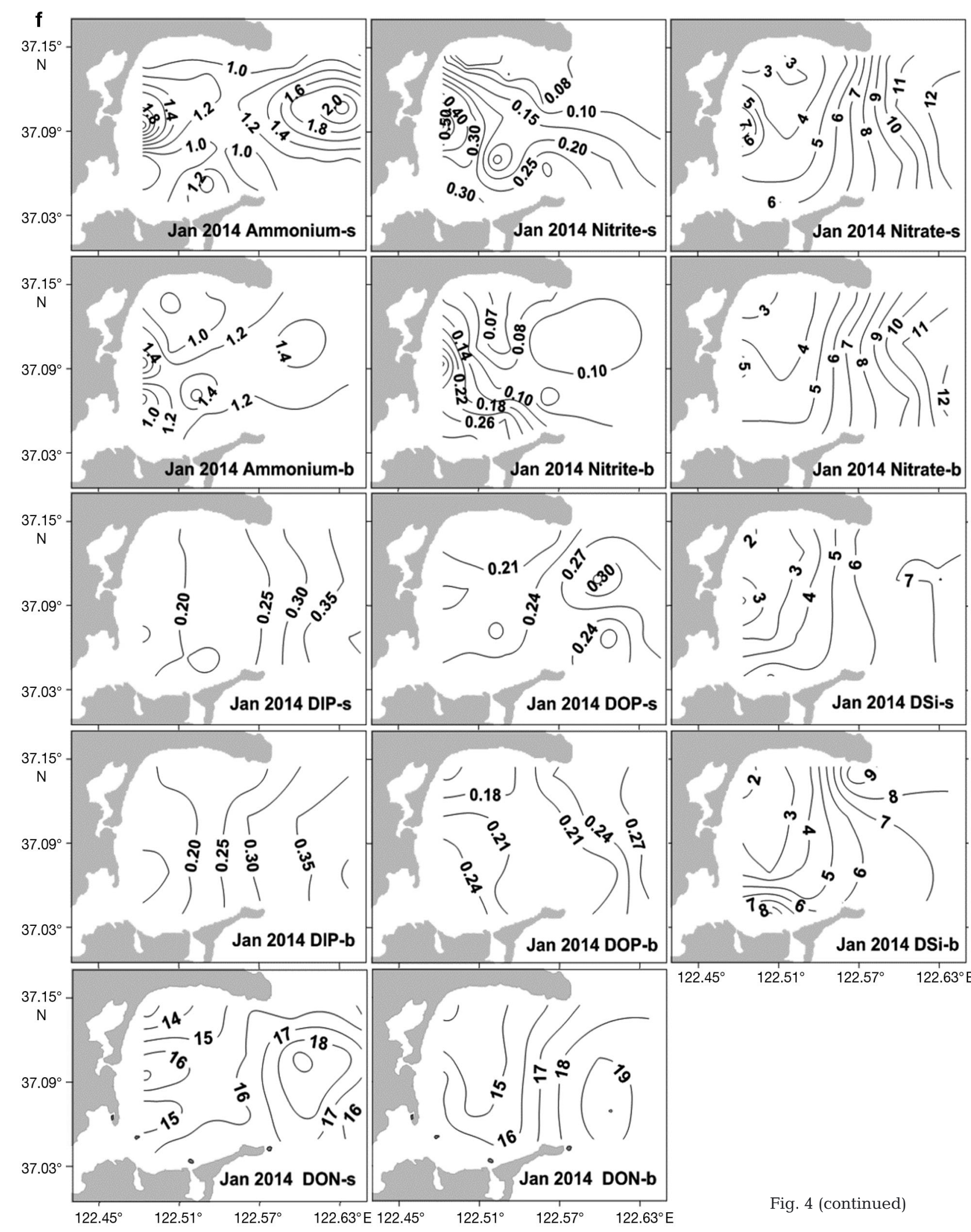



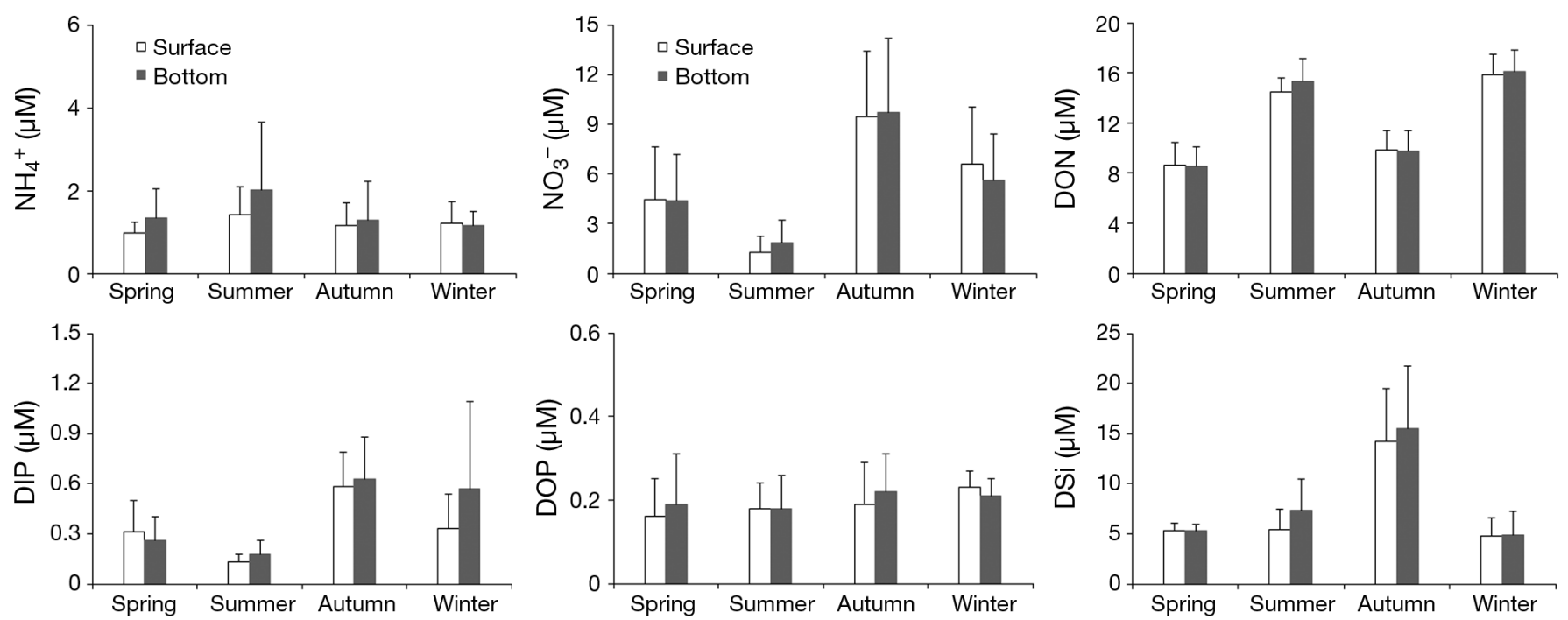

Fig. 5. Seasonal variations in nutrient concentrations $(\mu M)$ in Sanggou Bay during the study period. DON: dissolved organic nitrogen, DIP (DOP): dissolved inorganic (organic) phosphorus, DSi: dissolved silicate

cantly higher than the concentrations in spring and autumn (Fig. 4). TDN was dominated by DON (59-82\%), except in autumn (approximately $40 \%$ ). Two-way ANOVA indicated highly significant differences in nutrient concentrations among seasons and layers $(p<0.01)$. The subsequent post hoc Tukey's HSD test showed that the nutrient concentrations in autumn differed significantly from those in other seasons $(\mathrm{p}<0.01)$. Two-way ANOVA also indicated highly significant differences in nutrient concentrations among seasons and cultivation areas (Fig. 6 ; $p<$ 0.01 ), suggesting that aquaculture activities significantly affect the nutrient composition in SGB.

\section{Nutrients at the anchor stations}

In April 2013, all nutrients changed during the tidal cycle at Stn D1 (Fig. 7a). The maximum concentrations usually occurred during high tide, indicating the outer bay as a nutrient source. The vertical profiles for concentrations of all dissolved inorganic nutrients at Stn D1 showed that the water column was well mixed (Fig. 7a). High concentrations of DON (9.01-13.8 $\mu \mathrm{M})$ were found throughout the water column, and comprised up to $50 \%$ of TDN. The DIN: $\mathrm{PO}_{4}{ }^{3-}$ ratio ranged from 23 to 74 in surface water and from 30 to 132 in near-bottom water, and the DSi:DIN ratio ranged from 0.5 to 0.8 in surface water and from 0.4 to 0.9 in near-bottom water. At Stn D2, the nutrient concentrations were higher in nearbottom waters than in surface water, the exception being $\mathrm{NH}_{4}{ }^{+}$and DOP (Fig. 7a). The DON (8.26-
$10.5 \mu \mathrm{M})$ comprised $66-87 \%$ of TDN. The concentrations of DOP $(0.08-0.35 \mu \mathrm{M})$ represented $25-73 \%$ of TDP, and indicated a well-mixed profile. The DIN: $\mathrm{PO}_{4}{ }^{3-}$ ratio increased from $8.0-20$ in surface water to 11-37 in near-bottom water, while the DSi:DIN ratio decreased from 1.6-3.2 in surface water to $1.0-1.5$ in near-bottom water. The nutrient concentrations at Stn D1 were higher than at D2.

Analysis of the concentrations of all nutrients during 18-19 October 2013 showed that the water column at Stn D1 was well mixed (Fig. 7b). No parameter showed significant differences between day and night, indicating that tidal mixing was the main factor affecting concentration changes. The concentrations of DON were $5.38-10.5 \mu \mathrm{M}$, which comprised $26-83 \%$ of TDN. The DOP concentrations were $0.05-0.34 \mu \mathrm{M}$, which represented $8-39 \%$ of TDP. The DIN: $\mathrm{PO}_{4}{ }^{3-}$ ratio was $23-36$ (average 27 ) in surface water, and 22-51 (average 28) in bottom water. The DSi:DIN ratio was $0.7-1.0$ (average 0.9 ) in surface water and 0.5-1.0 (average 0.8 ) in bottom water. At Stn D2, the concentrations of all nutrients in surface water showed a general decrease with increasing tide height. The DIN: $\mathrm{PO}_{4}{ }^{3-}$ and DSi:DIN ratios in surface water ranged from 22 to 32 and 0.8 to 1.0 , respectively. The nutrient concentrations at Stn D1 were lower than at D2.

\section{Water and nutrient budgets in SGB}

Domestic wastewater is discharged directly into rivers adjacent to $\mathrm{SGB}$, and so in developing a water 


\section{Surface}
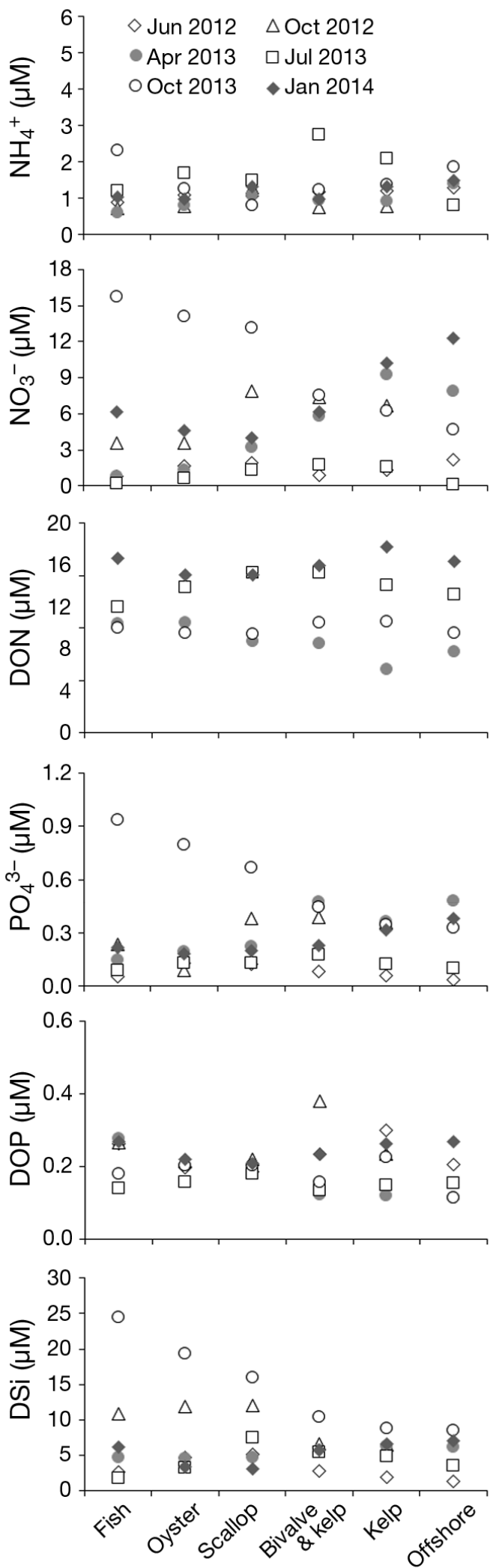

Bottom
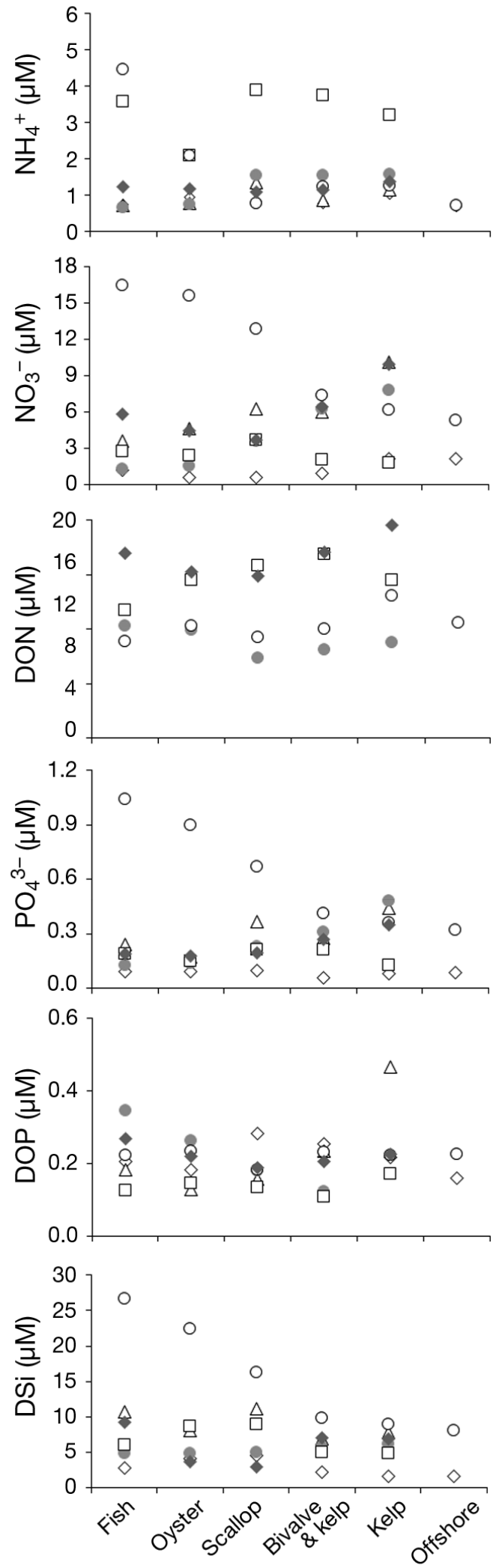

Fig. 6. Nutrient cycles, averaged for various aquaculture regions in Sanggou Bay Left: nutrients in surface water, right: nutrients in the near-bottom layer. DON: dissolved organic nitrogen, DOP: dissolved organic phosphorus, DSi: dissolved silicate 
budget for the bay, sewage discharge was included in river discharges. The Guhe is the largest major river that directly empties into SGB. In developing the water budget (Fig. 8), we used the average discharge $\left(V_{\mathrm{Q}}\right)$ of the Guhe during 2011. The submarine groundwater discharge (SGD) was estimated based on submarine groundwater measurements made in June 2012. The groundwater discharge into SGB was calculated to be $(2.59-3.07) \times 10^{7} \mathrm{~m}^{3} \mathrm{~d}^{-1}$, based on the naturally occurring ${ }^{228} \mathrm{Ra}$ isotope (Wang et al. 2014). Generally, recirculated seawater accounts for 75 to $90 \%$ of total SGD (Moore 1996). Based on Ra isotopes, Beck et al. (2008) reported that recirculated seawater could account for approximately $90 \%$ of total SGD, and could increase as a consequence of precipitation (Guo et al. 2008). In our study, groundwater samples were collected during a summer in which substantial rainfall occurred. Based on the assumption that recirculated seawater could account for $90 \%$ of total SGD in SGB, the SGD was estimated to be (2.59-3.07) $\times$ $10^{6} \mathrm{~m}^{3} \mathrm{~d}^{-1}$. As the volume $\left(V_{\mathrm{S}}\right)$ of SGB is $10.8 \times 10^{8} \mathrm{~m}^{3}$, the total water exchange time $(\tau)$ for $\mathrm{SGB}$, estimated from the ratio $V_{\mathrm{S}} /\left(V_{\mathrm{R}}+V_{\mathrm{X}}\right)$, was $22.4 \mathrm{~d}$.

Scallop (Chlamys farreri) and oyster (Crassostrea gigas) are the main shellfish cultured in SGB. Aquaculture wastewater effluents are discharged directly into the bay. The minimum individual wet weight of oysters and scallops at harvest are 40 and $23 \mathrm{~g}$ (Nunes et al. 2003), respectively, and $60000 \mathrm{t}$ of oyster (wet weight) and $15000 \mathrm{t}$ of scallop are harvested annually from the bay (data from Rongcheng Fishery Technology Extension Station). Based on these data, we estimated that bivalve cultivation involved approximately $2.15 \times 10^{9}$ individuals during 2012. Based on excretion rates determined for bivalves and oysters in Sishili Bay (China) (Zhou et al. 2002a), the quantities of DIN and phosphate excreted by scallops were 3.84 and $0.21 \mu \mathrm{mol} \mathrm{h}^{-1}$ ind. $^{-1}$, respectively, and by oysters were 3.57 and $0.25 \mu \mathrm{mol} \mathrm{h} \mathrm{h}^{-1}$ ind. ${ }^{-1}$, respectively. The bivalve growth
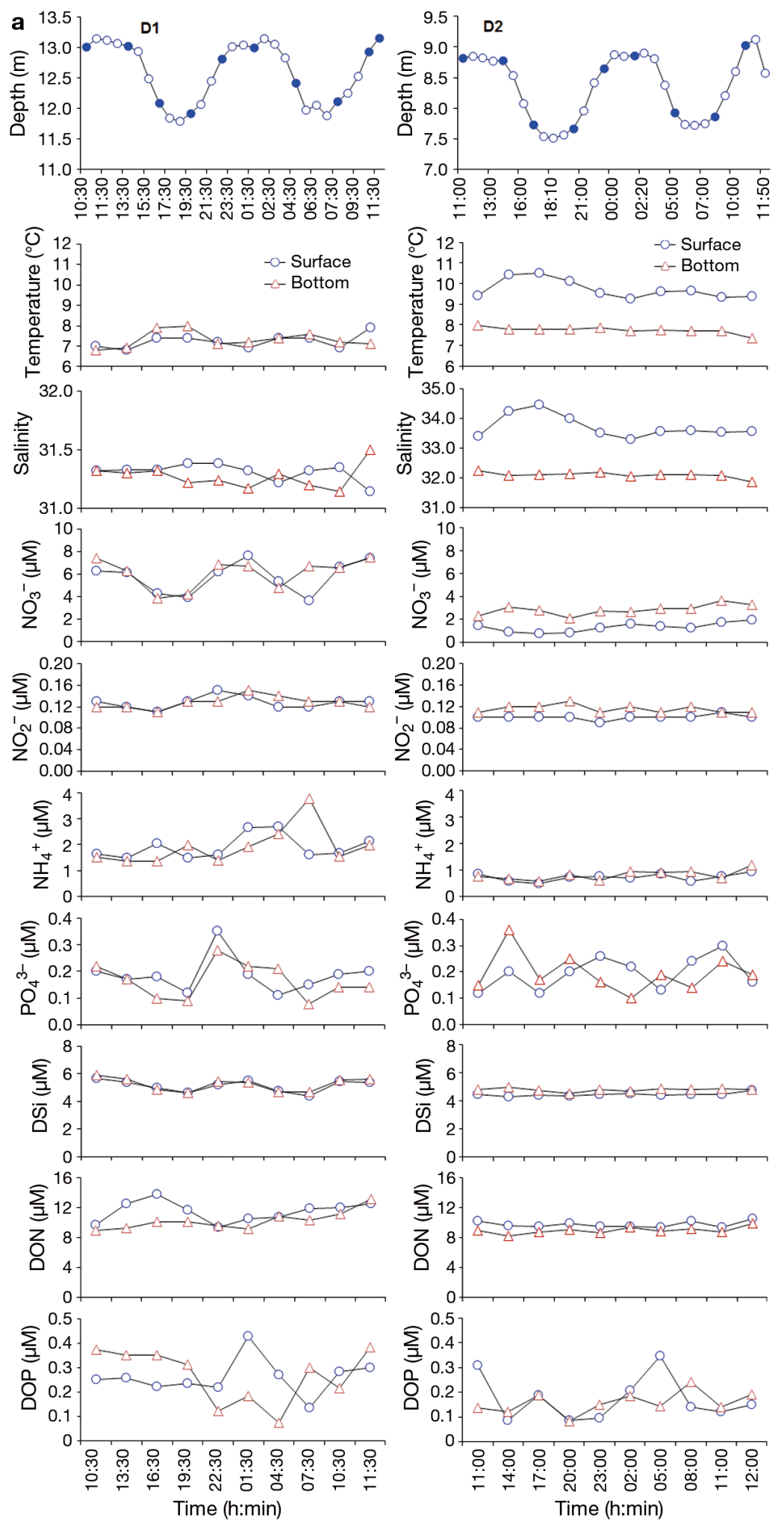

Fig. 7. Concentrations of nutrients $(\mu \mathrm{M})$ at: (a) the anchor station in April 2013; (b; next page) the anchor station in October 2013. The water depth (m) in April 2013 and tide heights (cm) in October 2013 are provided, and the filled circles represent the nutrient sampling times. DSi: dissolved silicate, DON (DOP): dissolved organic nitrogen (phosphorus) 

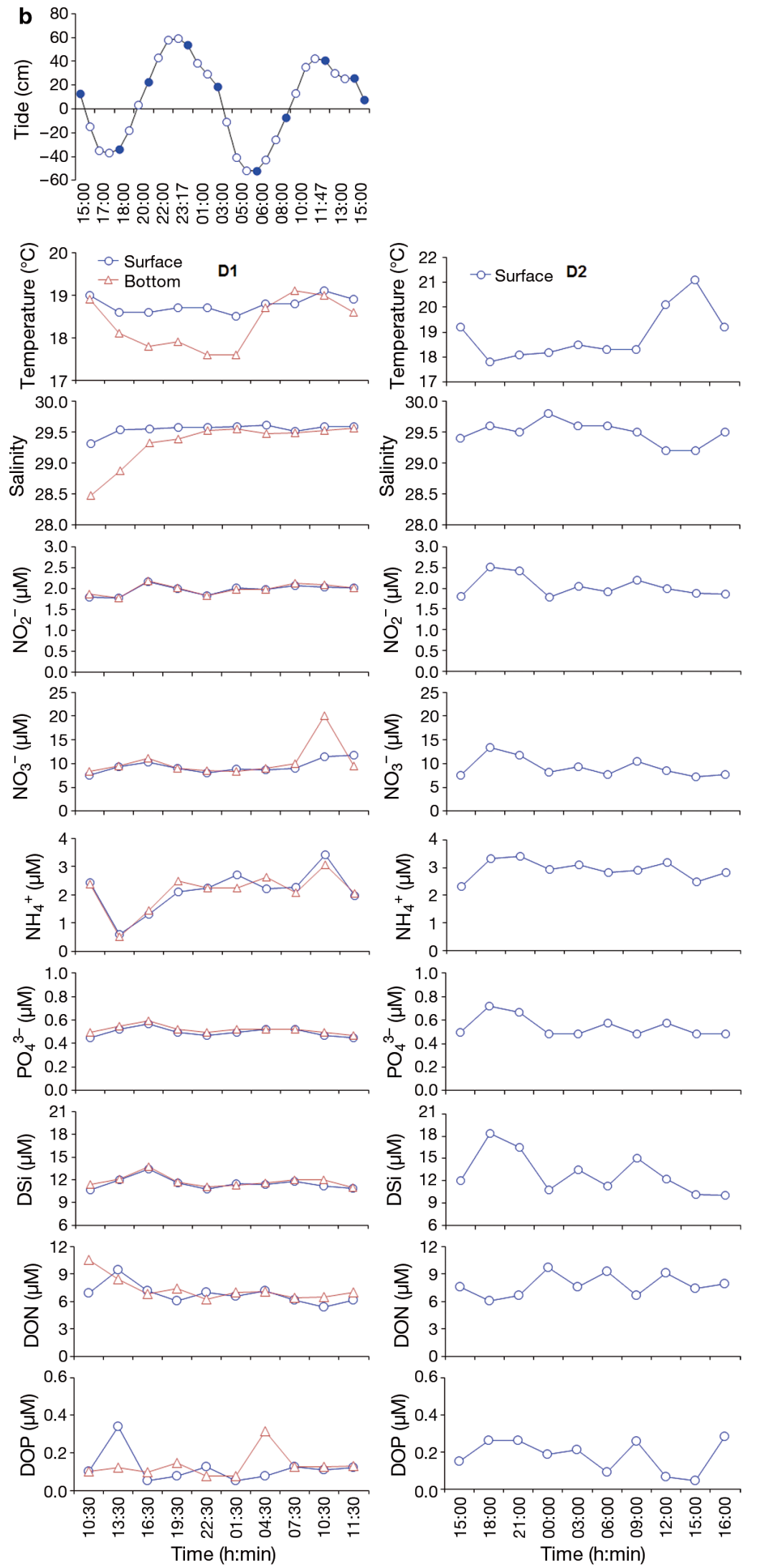

Fig. 7 (continued) periods were mainly from May in one year to November in the following year (approximately $500 \mathrm{~d}$ ). Hence, the total DIN and phosphate excreted by scallops and oysters in SGB amounted to $70.9 \times 10^{6}$ and $4.19 \times 10^{6} \mathrm{~mol} \mathrm{yr}^{-1}$, respectively. Nutrients are removed from the bay as a consequence of bivalve harvest. The dry weight nitrogen content of the soft tissue and shell of C. gigas is 8.19 and $0.12 \%$ (Zhou et al. $2002 b)$, respectively, while the phosphorus content is 0.379 and $62.1 \times 10^{-4} \%$ (Zhou et al. 2002b), respectively. The dry weight nitrogen and phosphorus content of the soft tissue of C. farreri is 12.36 and $0.839 \%$ (Zhou et al. 2002b), respectively, and in the shell is 0.09 and $62.1 \times 10^{-4} \%$, respectively. Therefore, in total the harvest of $C$. farreri and C. gigas removes $304 \mathrm{t}$ of nitrogen and $16.7 \mathrm{t}$ of phosphorus from the bay.

Saccharina japonica and Gracilaria lemaneiformis are the main algae cultivated in SGB. The weight of individual kelp plants at seeding is $1.2 \mathrm{~g}$, and the cultivation area and density are 3331 ha and 12 ind. $\mathrm{m}^{-2}$, respectively (Nunes et al. 2003). The dry weight:wet weight ratio of kelp is 1:10 (Tang et al. 2013). Hence, the dry weight of kelp at seeding is $48 \mathrm{t}$, while $87040 \mathrm{t}$ of dried kelp are produced annually in the bay (data from Rongcheng Fishery Technology Extension Station). The dry weight nitrogen and phosphorus content of kelp is 1.63 and $0.38 \%$ (Zhou et al. $2002 b)$, respectively. Hence, 1419 t of nitrogen and $331 \mathrm{t}$ of phosphorus are removed from the bay as a consequence of kelp harvest. Similarly, 25410 t wet weight of $G$. lemaneiformis are produced annually in the bay (data from Rongcheng Fishery Technology Extension Station). Therefore, $41.4 \mathrm{t}$ of nitrogen and $9.66 \mathrm{t}$ of phosphorus are removed from the bay as a consequence of G. lemaneiformis harvesting.

The nutrient transport fluxes from rivers and groundwater into SGB were determined from surveys undertaken during the period 2012 to 2014. The nutrient concentrations in rainwater were based on measurements at Qianliyan Island, in the western Yellow Sea (Han et al. 2013). Benthic fluxes in SGB were based on surveys undertaken during the same period 


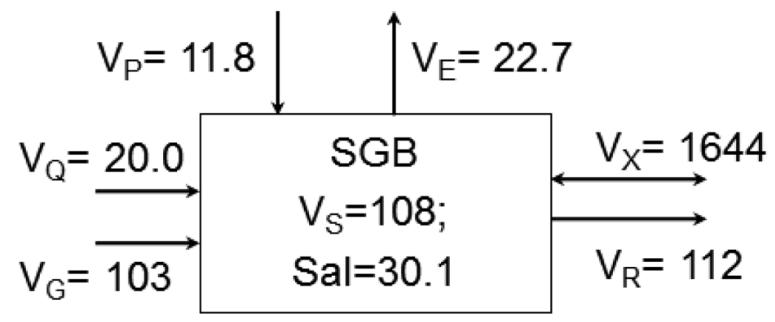

Fig. 8. Water and salt budgets for Sanggou Bay (SGB). Units: water volume, $10^{7} \mathrm{~m}^{3}$; water and salt fluxes, $10^{7} \mathrm{~m}^{3}$ and $10^{7}$ psu $\mathrm{m}^{3} \mathrm{mo}^{-1}$, respectively. $V_{\mathrm{Q}}, V_{\mathrm{P}}, V_{\mathrm{E}}, V_{\mathrm{G}}, V_{\mathrm{S}}, V_{\mathrm{R}}$ and $V_{\mathrm{X}}$ are the mean flow rate of river water, precipitation, evaporation, groundwater, the volume of the system of interest, the residual flow, and the mixing flow between the system of interest and the adjacent system, respectively. For comparison, salinity of the adjacent system $=32.23$

(Ning et al. 2016, this Theme Section). For the nutrient budget, estimates of DSi removed through kelp and bivalve harvesting were not included, as no data were available.

The nutrient budgets showed that SGB behaved as a source of $\mathrm{PO}_{4}{ }^{3-}$ and as a sink of DSi and DIN (Table 3). The model results indicated that $\mathrm{PO}_{4}{ }^{3-}$ was mainly derived from bivalve excretion, which accounted for $65 \%$ of total influx, while benthic flux contributed $16 \%$ of total influx. Bivalve excretion may be an important source of $\mathrm{PO}_{4}{ }^{3-}$ when phytoplankton growth is phophorus-limited in the bay. The DSi load in the bay was mainly from river input and benthic flux, which contributed 47 and $34 \%$ of total influx (Table 3), respectively. Groundwater was the major source of DIN entering SGB, accounting for
$41 \%$ of total influx. In addition, bivalve excretion accounted for $19 \%$ of total DIN influx. DIN and $\mathrm{PO}_{4}{ }^{3-}$ were mainly removed through kelp harvesting, which represented up to 64 and $81 \%$ of total outflux, respectively. The results show that aquaculture activities play an important role in nutrient cycling in SGB.

\section{DISCUSSION}

\section{Nutrient transport in rivers}

Nutrient levels in rivers varied widely (Table 2). The DIN concentrations in the rivers fell between those for polluted waters $(110 \mu \mathrm{M})$ and severely polluted waters $(350 \mu \mathrm{m})$ (Smith et al. 2003), except for the Bahe river. The DIN concentrations in the studied rivers were also higher than in most other small to medium-sized rivers in temperate China (Liu et al. 2009), and high relative to major Chinese rivers including the Yellow, Yangtze, and Pearl rivers (Liu et al. 2009). The extremely high DIN concentrations resulted in the high DIN: $\mathrm{PO}_{4}{ }^{3-}$ ratios in these rivers.

The DIN loading to streams is directly related to the extent of agriculture in the catchment (Heggie \& Savage 2009). The high $\mathrm{NO}_{3}{ }^{-}$concentrations, which dominated the DIN in rivers, is primarily attributable to anthropogenic nutrient sources, particularly to washout of fertilizers not used by target plants (Bellos et al. 2004). Rivers in the study area flow through villages and Rongcheng City, then discharge directly into SGB. Untreated industrial and domestic sewage is also discharged directly into rivers. The drainage

Table 3. Nutrient budgets for Sanggou Bay, China. $V_{\mathrm{R}} C_{\mathrm{R}}$ : residual nutrient transport out of the system of interest (Eq. 1$) ; V_{\mathrm{X}} C_{\mathrm{X}}$ : mixing exchange flux of nutrients (Eq. 2); influx (outflux): total nutrient flux into (out of) the system of interest. $\Delta$ (= $\sum$ outflux $\sum$ influx) is the non-conservative flux of nutrients. Negative and positive signs of $\Delta$ indicate that the system is a sink or a source, respectively. DIP (DIN): dissolved inorganic phosphorus (nitrogen), DSi: dissolved silicate (units: $10^{6} \mathrm{~mol}$ )

\begin{tabular}{|c|c|c|c|c|}
\hline & DIP & DSi & DIN & Reference \\
\hline River input ( $\left.V_{\mathrm{Q}} C_{\mathrm{Q}}\right)$ & 0.29 & 22.4 & 83.2 & Present study \\
\hline Atmospheric deposition $\left(V_{\mathrm{P}} C_{\mathrm{P}}\right)$ & 0.41 & 0.87 & 14.6 & Han et al. (2003) \\
\hline Groundwater discharge $\left(V_{\mathrm{G}} C_{\mathrm{G}}\right)$ & 0.55 & 8.27 & 155 & Wang et al. (2014) \\
\hline Benthic fluxes & 1.05 & 16.3 & 57.8 & Ning et al. (2016) \\
\hline Bivalve excretion & 4.19 & & 70.9 & Zhou et al. $(2002 \mathrm{a}, \mathrm{b})$ \\
\hline Influx & 6.49 & 47.8 & 382 & \\
\hline Kelp harvest & -10.7 & & -101 & Zhou et al. $(2002 a, b)$ \\
\hline Gracilaria lemaneiformis harvest & -0.32 & & -2.96 & Zhou et al. $(2002 a, b)$ \\
\hline Bivalve harvest & -1.19 & & -21.7 & Zhou et al. (2002a,b), Zhang et al. (2013) \\
\hline Residual flow $\left(V_{\mathrm{R}} C_{\mathrm{R}}\right)$ & -0.38 & -8.26 & -7.31 & Present study \\
\hline Mixing exchange $\left(V_{\mathrm{X}} C_{\mathrm{X}}\right)$ & -0.65 & -16.1 & -26.2 & Present study \\
\hline Outflux & 13.2 & 24.4 & 159 & \\
\hline$\Delta Y\left(=\sum\right.$ outflux $-\sum$ influx $)$ & 6.71 & -23.4 & 223 & \\
\hline
\end{tabular}


areas of the Yatouhe, Sanggouhe, and Shilihe rivers are small $\left(<30 \mathrm{~km}^{2}\right)$ and are therefore readily affected by human activities. We conclude that the high $\mathrm{NO}_{3}{ }^{-}$concentrations in rivers are derived from agriculture, urban, and industrial wastewater in their drainage basins, as well as surface runoff from Rongcheng City.

The concentrations of $\mathrm{PO}_{4}{ }^{3-}$ in the Bahe and Guhe rivers were between those for pristine $(0.5 \mu \mathrm{M})$ and clean $(1.4 \mu \mathrm{M})$ water, and apparently lower than in the Shilihe and Sanggouhe rivers (Table 2). The high $\mathrm{PO}_{4}{ }^{3-}$ concentration (up to $6.02 \mu \mathrm{M}$ ) in the Sanggouhe, and industrial and domestic sewage, might be the most important sources of $\mathrm{PO}_{4}{ }^{3-}$ to water bodies. DSi is little affected by human activities (Jennerjahn et al. 2009) and mainly originates from natural sources. The high DSi levels in rivers adjacent to SGB may be related to the underlying rock types and weathering rates.

Rain events can result in nutrient inputs derived from hinterland areas. Approximately $73.3 \%$ of annual precipitation occurs during summer (June to September), and the annual rainfall in Rongcheng City is $819.6 \mathrm{~mm}$. River discharges can be enhanced by rainfall, and weathering rates are affected by precipitation and temperature (Liu et al. 2011), which can lead to higher nutrient values during the wet seasons. High nutrient concentrations (especially dissolved silicate) but low salinities were found in the bay (Fig. 4), suggesting that rainfall might be an important factor affecting nutrient supply to SGB in summer.

\section{Nutrient fluxes from the bay to the Yellow Sea}

In this study, nutrient budgets were developed to provide an overview of nutrient cycles under the impact of aquaculture activities. Despite some uncertainties, the nutrient budgets indicated that large quantities of nitrogen and silicate would probably be buried in the sediment or transformed into other forms in the bay (Table 3). Seaweeds can absorb large amounts of nutrients from the water column, resulting in the removal of these nutrients from the system when the plants are harvested (Schneider et al. 2005). The budgets indicated that a large proportion of DIN and DIP were removed during seaweed and bivalve harvesting (Table 3), demonstrating that aquaculture activities are a significant sink for nutrients in the bay.

Based on the budgets, nutrient fluxes from SGB to the Yellow Sea were estimated as the sum of the net residual flux $\left(V_{\mathrm{R}} C_{\mathrm{R}}\right)$ and mixing flux $\left(V_{\mathrm{X}} C_{\mathrm{X}}\right)$ (Table 3). With the exception of DIN, nutrient fluxes to the Yellow Sea were 1.1 to 3.6 times the riverine input $\left(F_{\text {model }}=V C_{\mathrm{Q}}\right)$, indicating that nutrient cycling in the bay (including regeneration, aquaculture effluents) may magnify the riverine fluxes, especially bivalve excretion, which contributed to $65 \%$ of the total DIP influx. Additionally, the molar ratios of DIN:PO ${ }_{4}{ }^{3-}$ and DSi:DIN were approximately 49 and 0.2 in all external nutrient inputs to the studied system, respectively, while the corresponding flux ratios in the output waters to the Yellow Sea were approximately 35 and 0.7 . These ratios deviated significantly from the Redfield ratio, indicating that aquaculture activities have significantly influenced nutrient cycling in the bay.

Wang et al. (2014) estimated that approximately $4.76 \times 10^{7} \mathrm{~mol} \mathrm{mo}^{-1}$ of DIN and $5.58 \times 10^{6} \mathrm{~mol} \mathrm{mo}^{-1}$ of $\mathrm{PO}_{4}{ }^{3-}$ are input from fertilizer and feed, based on protein data of shellfish and kelp in the bay during summer being used to construct a mass balance. Based on their data, fertilizer and feed would be the major source of nutrients in the bay. By visiting local farming households, we confirmed that fertilizers were used; however, fertilizer and feed are only used in fish farming during summer in SGB, thus the amounts might be far below the estimated values. If fertilizer and feed for fish farming were taken into account, the uncertainty might rise. Hence, nutrient input from feed was ignored in the box model. Furthermore, aquaculture effluents were not taken into account. Consequently, more studies on nutrient cycling in relation to aquaculture activities in SGB are needed to improve our understanding of the nutrient sink or source function of the bay.

\section{Effects of aquaculture activities on nutrient biogeochemical cycles}

The nutrient concentrations varied significantly among seasons in SGB. The dissolved inorganic nutrient levels in SGB in summer were quite low compared with other seasons; they increased from summer to autumn and reached the highest values in October (Figs. 4 \& 5), indicating a shift from consumption to autumn accumulation. These seasonal variations corresponded with aquaculture activities in the bay, and this was confirmed by statistical analysis. Zhang et al. (2012) reported that nutrient biogeochemical processes and cycles were significantly affected by intensive kelp and bivalve aquaculture activities in SGB. Shi et al. (2011a) also reported that 
Saccharina japonica assimilates substantial nutrients in spring. During the growth period of kelp from November to May, the $\mathrm{NO}_{3}{ }^{-}$and $\mathrm{PO}_{4}{ }^{3-}$ concentrations decreased rapidly because of assimilation by kelp (Fig. 6). Nitrogen removed through kelp harvesting accounted for $64 \%$ of total outflux (Table 3). Kelp was a net sink for nutrients during winter and spring, and competed with phytoplankton for nutrient utilization during kelp seeding; as a consequence, phytoplankton growth was restrained. Following the kelp harvest in late May, phytoplankton could grow fast because of adequate solar radiation and temperature. As a result, the dissolved inorganic nutrient concentrations continued to decrease (Figs. 4-6).

Shellfish aquaculture generally commences in May, during the period when kelp is harvested. Bivalves in turn become another source of nutrients through excretion. During early summer, the bivalves are in the early growth stage, and produce only low levels of nutrients. The dissolved nutrients released through bivalve excretion have the potential to stimulate phytoplankton production at local scales and promote the risk of harmful algal blooms (Pietros \& Rice 2003, Buschmann et al. 2008). The highest concentrations of chlorophyll a have been reported in summer (Hao et al. 2012). The dissolved nutrients in aquaculture effluents, coupled with high solar radiation, result in high phytoplankton production in summer (Shpigel 2005). At this time, Gracilaria lemaneiformis replaces kelp, and is cultivated from June to October in SGB; because it can use available nitrogen efficiently (Buschmann et al. 2008), it absorbs nutrients from seawater and probably reduces the nutrient levels in summer. This probably leads to the nutrient levels dropping rapidly to the lowest level in summer (Fig. 6).

In September, the bivalves are in active growth stages and generate large quantities of metabolic byproducts. The maximum metabolic rates for oysters are recorded in July and August (Mao et al. 2006), and lead to high nutrient concentrations in seawater (Fig. 5). Bivalves filter phytoplankton larger than 3 $\mu \mathrm{m}$ in size, thereby reducing their biomass in the water column (Newell, 2004). Phytoplankton growth is also limited by the level of solar radiation (Shi et al. $2011 \mathrm{~b}$ ). Thus, as nutrient utilization by phytoplankton decreased, the dissolved inorganic nutrient concentrations increased as a result, and increased to a greater extent in regions where bivalve monoculture occurred. Based on the nutrient budget in our study, phosphorus released from bivalve excretion could account for $65 \%$ of total influx to SGB. Hence, from June to October, prior to kelp seeding, bivalves and fish excretion may constitute an important nutrient source in SGB, leading to increased nutrient levels. Particulate waste material (feces or pseudofeces) from bivalves and phytoplankton are consumed by bivalves, and the nutrients involved may be removed through bivalve harvesting (Shpigel 2005, Troell et al. 2009). As top-down grazers, bivalves filter phytoplankton, which results in a reduction in the nutrient turnover time and speeds up nutrient cycling.

Nutrients can be produced indirectly via remineralization and subsequent release from enriched sediments (Forrest et al. 2009). Nutrient release from sediment is also a common phenomenon occurring beneath bivalve farms in SGB (Cai et al. 2004, Sun et al. 2010). The nutrient budgets also show that benthic flux is another important source of nutrients in SGB, especially for DIP and DSi (Table 3), and that this is significantly affected by aquaculture activities in the bay (Ning et al. 2016). Based on studies of other bivalve culture systems and natural or restored oyster reefs, it is evident that benthic fluxes are determined by processes involving filter feeding and excretion of dissolved nutrients, as well as biodeposition and sediment remineralization of nutrients (Newell 2004, Forrest et al. 2009). The TDN in SGB was dominated by DON in both summer and winter (Figs. 4 \& 5), as observed in landbased aquaculture (Jackson et al. 2003, Herbeck et al. 2013). Burford \& Williams (2001) reported that most of the dissolved nitrogen leaching from feed and shrimp feces was in organic rather than in inorganic forms. Hence, DON leaching from feces or pseudofeces might be an important source of DON in the bivalve cultivation regions in SGB (Fig. 6). Furthermore, increased sedimentation of organic matter from feces and pseudofeces underneath mussel farms can have significant ecosystem effects on the biogeochemical cycles of nitrogen and phosphorus (Stadmark \& Conley 2011).

Biogeochemical cycling of DSi can be affected by diatom dissolution, sediment resuspension, and terrigenous input. In our study, the average concentrations of DSi increased by $9.0 \mu \mathrm{M}$ from July to October, and decreased rapidly from 14.2 to $4.76 \mu \mathrm{M}$ in January. Phytoplankton abundance was tightly controlled by filter feeding of oysters (Hyun et al. 2013), so the high metabolic rates of oysters may result in a reduction of diatom biomass, leading to high levels of DSi in autumn. In addition, as the water depth in SGB is $\leq 20 \mathrm{~m}$, sediment resuspension and diatom dissolution might be important sources of DSi during the summer to autumn period. The dissolution of diatom frustules depends on a variety of factors, including microbial activity (Olli et al. 2008). Bacteria can 
attack the organic matrix protecting the diatom frustule, exposing biogenic silica, and substantially increase the dissolution rate (Bidle \& Azam 1999). The maximum biomass in SGB occurred in autumn (Chen 2001), and diatoms dominated in the bay in summer. Consequently, dissolution of diatom frustules may be an important source of DSi in the bay.

Although the aquaculture area and quantities of effluents released in SGB were high (Table 3), nutrient levels in the bay were not significantly elevated compared with other bays used for aquaculture, including Jiaozhou Bay (Liu et al. 2007) and Sishili Bay (Zhou et al. 2002b). This is attributed to the fact that nutrients released from shellfish are taken up by seaweeds during their growth periods. Large-scale kelp cultivation plays an important role in keeping nutrients at low levels and maintaining relatively good water quality.

\section{Effects of physical factors on nutrient changes}

The marine IMTA culture system used in SGB is suspended aquaculture. Water exchange between SGB and the Yellow Sea could be hindered by kelp (S. japonica), especially during kelp harvesting (Zeng et al. 2015). Our depth study showed that nutrien changes over the tidal cycle generally closely followed changes in water depth at Stn D2 (Fig. 7), indicating that water exchange is greater at Stn D1 (in the northern mouth of SGB), and weaker at Stn D2. Furthermore, in April 2013, the nutrients were well mixed at Stn D1, while at Stn D2, the nutrient concentrations were higher in bottom water than in the surface water (Fig. 7). This indicates that the current was affected by the aquaculture facilities and kelp at Stn D2, which may have led to higher nutrient concentrations in the bottom water than in the surface water. These results are consistent with the in situ measurements of Zeng et al. (2015), which showed that the vertical tidal flux at the northern entrance of SGB was much larger than at the southern entrance. In addition, the current structure in SGB has been significantly changed by the presence of aquaculture activities (Shi et al. 2011a). The tidal current in the surface layer is only half that in the middle layer when kelp is at its maximum length (Shi et al. 2011a). As a result, particulate matter and nutrients in bottom waters are constrained from entering the upper water layers because of the influence of aquaculture facilities and species (Wei et al. 2010).

The current flow generally tends to decrease in suspended aquaculture areas because of the extra drag caused by the presence of aquaculture facilities. In SGB, bivalves and fish are grown in cages, nets, or other containers hung from floats or rafts. Based on a 3-dimensional physical-biological coupled aquaculture model (Shi et al. 2011a), the average current flow speed can be reduced by approximately $63 \%$ by aquaculture facilities and cultured species. Moreover, Grant \& Bacher (2001) reported a $20 \%$ reduction in current speed in the main navigation channel in $\mathrm{SGB}$, and a $54 \%$ reduction in the middle of the culture area because of the effects of suspended aquaculture. Nutrients are likely to be retained in the bay because of the weaker current in the bivalve culture areas. The nutrient budgets showed that bivalve excretion was an important source of nutrients (Table 3). Large quantities of nutrients could accumulate in the west of the bay, and red tides have occurred in SGB in recent years (Zhang et al. 2012). The effects of consequent shading and competition pressure from the increased algae biomass on the valuable habitats involved may negatively affect the seagrass meadows in the southwest of the bay, and the production of bivalves may be reduced. To conserve the natural services provided by the bay, aquaculture effluents should be treated before they are released into natural water bodies.

Water exchange can also cause differences in nutrient species inside and outside SGB. Wei et al. (2010) observed that the flow speed declined by approximately $70 \%$ from the mouth to the southwestern part of the bay, and the outflow was slowed by the increased aquaculture activities and infrastructure (Fan \& Wei 2010). Thus, movement of nutrients from the southwest of the bay to the open sea may be impeded, which was suggested by the high concentrations of nutrients found in this part of the bay in summer and autumn (Fig. 4).

\section{Long-term trends of nutrients in SGB}

Fig. 9 shows compiled data for DIN, $\mathrm{DSi}$, and $\mathrm{PO}_{4}{ }^{3-}$ in SGB, based on historical data and our observations (Song et al. 1996, P. Sun et al. 2007, S. Sun et al. 2010, Zhang et al. 2010, 2012, this study), reflecting the long-term variations for the period 1983 to 2014. No trends in the $\mathrm{PO}_{4}{ }^{3-}$ concentrations were evident because of the high variability in this parameter (Fig. 9). In contrast, the DIN concentrations increased over time and were significantly higher in 2003 to 2011 than in previous years (Fig. 9). Prior to the 1980s, kelp was the main aquaculture species, and the DIN concentration was low in the bay (Fang et al. 1996a, 

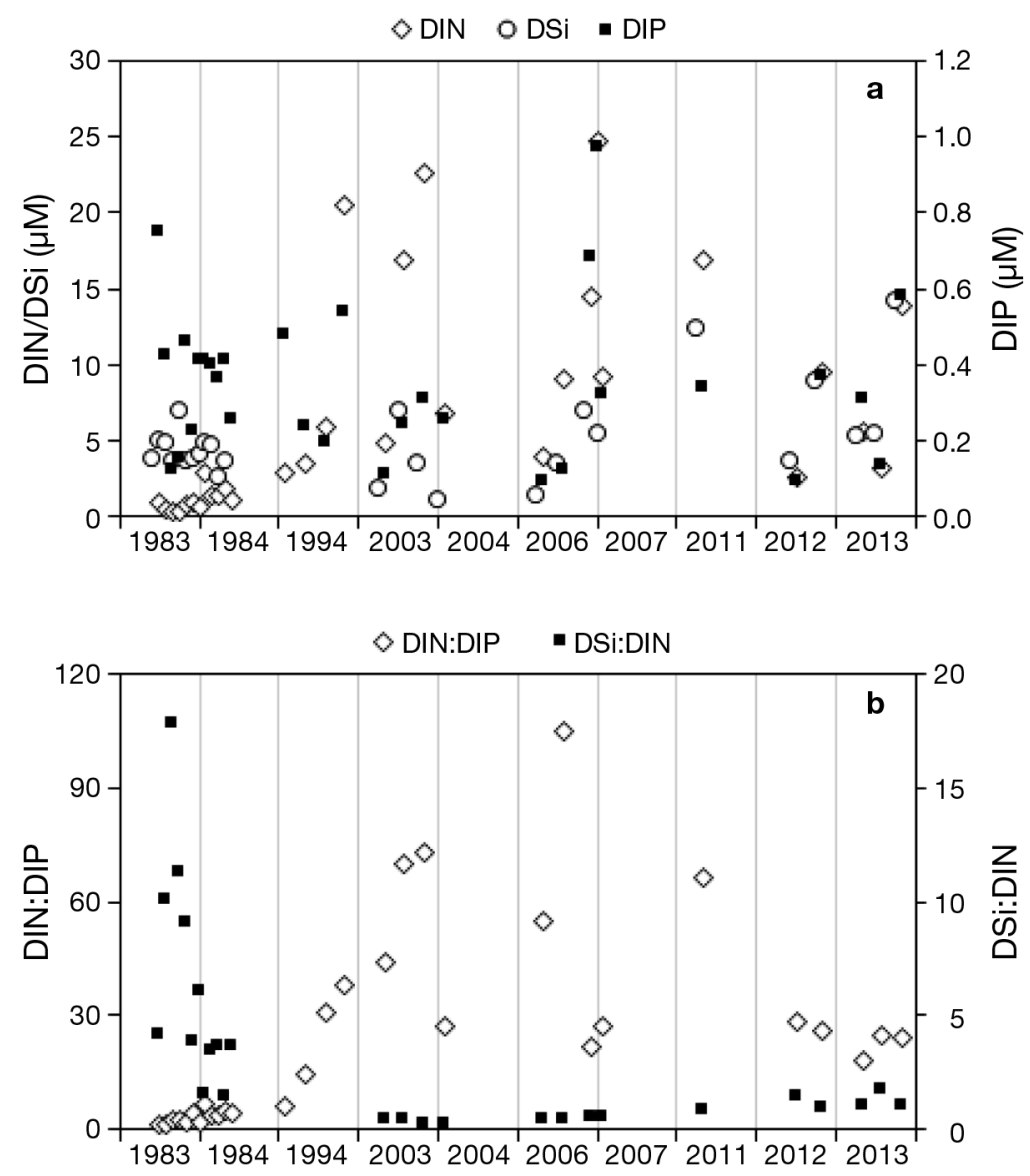
ganic nitrogen (DIN), dissolved inorganic phosphorus (DIP), and dissolved silicate (DSi) concentrations, and (b) the DIN:PO ${ }_{4}{ }^{3-}$ and DSi:DIN ratios for the period 1983 to 2013
Fig. 9. Long-term changes in (a) the concentrations of dissolved inor-

bays used for aquaculture, including Chesapeake Bay in the US (Tango et al. 2005), and Jiaozhou (Shen 2002, Sun et al. 2011) and Daya Bays (Wang et al. 2009) in China. Turner et al. (1998) reported that the risk of harmful algal blooms increases with shifts in the DSi:DIN ratio to values $<1$, when phytoplankton becomes dominated by nondiatom species. Molar ratios of DSi:DIN in SGB changed from 1.4-18 in 1983 to <1 during the 2003 to 2011 period. Red tides were observed in April 2011 (Zhang et al. 2012), and were apparent in small areas in 2013. In addition, an increase in the DIN concentration will lower the DSi:DIN ratio, and could change ecosystem structure of the bay (Billen \& Garnier 2007).

Because of its combination of environmental, economic, and social benefits (Allsopp et al. 2008, Nobre et al. 2010), IMTA has been gaining recognition as a sustainable approach to aquaculture, and the water quality in SGB has remained in good condition compared with other bays affected by aquaculture activities. Environmental management strategies will need to include both reduction of nutrient pollution and monitoring of the relative abundance of nutrients. The ecological and economic health of SGB should be tightly monitored to ensure a rapid response to critical changes.

\section{CONCLUSION}

bay rapid development may have been responsible for increasing levels of nutrients in the bay, and resulted in long-term alterations to the nutrient conditions (Shi et al. 2011a, Zhang et al. 2012). In SGB, nutrientrich aquaculture effluents are released into the natural water body without prior treatment. The high concentrations of nitrogen in aquaculture effluents mainly originate from excess feed or from excretion from the farmed animals (Burford \& Williams 2001).

As a result of the increased nitrogen levels, the DIN:DIP ratios in SGB shifted from severe nitrogen limitation in 1983 to the ecologically desirable Redfield ratio (16) in summer 1994, and continued to increase until summer 2006, when the DIN:PO ${ }_{4}{ }^{3-}$ ratio reached 105; phytoplankton growth is now limited by phosphorus in summer. The increase in the DIN:PO ${ }_{4}^{3-}$ ratios in SGB is a common phenomenon observed in long-term studies of estuarine and coastal areas affected by human activities, and also in semi-closed
We have reported on the nutrient dynamics of SGB, which represents a typical watershed for IMTA. The results of our investigation show that aquaculture activities play an important role in nutrient cycling in SGB. Nutrients showed considerable seasonal variation in the bay, and nutrient composition and distribution were also affected by the cultured species in the bay. The nutrient budgets showed that SGB behaved as a source of $\mathrm{PO}_{4}{ }^{3-}$ and as a sink of DSi and DIN. The model results indicated that $\mathrm{PO}_{4}{ }^{3-}$ was mainly derived from bivalve excretion. Bivalve excretion may be an important source of $\mathrm{PO}_{4}{ }^{3-}$ when phytoplankton growth is phosphorus-limited in the bay. Seaweed and bivalve harvesting play an important role in removing DIN and $\mathrm{PO}_{4}{ }^{3-}$ from the bay. Under the combined effects of natural processes and aquaculture activities, nutrient biogeochemistry in the bay has been affected. 
Acknowledgements. This research was funded by the Chinese Ministry of Science and Technology (2011CB409802), the Natural Sciences Foundation of China (NSFC: 41221004), and the Taishan Scholars Programme of Shandong Province. We thank colleagues at the Yellow Sea Fisheries Research Institute, Chinese Academy of Fishery Sciences, East China Normal University, and the Ocean University of China for their help during field investigations.

\section{LITERATURE CITED}

Allsopp M, Johnston P, Santillo D (2008) Challenging the aquaculture industry on sustainability. Greenpeace International, Amsterdam

Bacher C, Grant J, Hawkins AJS, Fang JG, Zhu MY, Besnard M (2003) Modelling the effect of food depletion on scallop growth in Sungo Bay (China). Aquat Living Resour 16:10-24

Beck AJ, Rapaglia JP, Kirk Cochran J, Bokuniewicz HJ, Yang SH (2008) Submarine groundwater discharge to Great South Bay, NY, estimated using Ra isotopes. Mar Chem 109:279-291

Bellos D, Sawidis T, Tsekos I (2004) Nutrient chemistry of River Pinios (Thessalia, Greece). Environ Int 30:105-115

Bidle KD, Azam F (1999) Accelerated dissolution of diatom silica by marine bacterial assemblages. Nature 39:508-511

> Billen G, Garnier J (2007) River basin nutrient delivery to the coastal sea: assessing its potential to sustain new production of non-siliceous algae. Mar Chem 106:148-160

Bostock J, McAndrew B, Richards R, Jauncey K and others (2010) Aquaculture: global status and trends. Philos Trans R Soc Lond B Biol Sci 365:2897-2912

Bouwman AF, Pawłowski M, Liu C, Beusen AHW, Shumway SE, Glibert PM, Overbeek CC (2011) Global hindcasts and future projections of coastal nitrogen and phosphorus loads due to shellfish and seaweed aquaculture. Rev Fish Sci 19:331-357

Burford MA, Williams KC (2001) The fate of nitrogenous waste from shrimp feeding. Aquaculture 198:79-93

- Buschmann AH, Varela DA, Hernández-González MC, Huovinen P (2008) Opportunities and challenges for the development of an integrated seaweed-based aquaculture activity in Chile: determining the physiological capabilities of Macrocystis and Gracilaria as biofilters. J Appl Phycol 20:571-577

Cai LS, Fang JG, Dong SL (2004) Preliminary studies on nitrogen and phosphorus fluxes between seawater and sediment in Sungo Bay. Mar Fish Res 25:57-64 (in Chinese with English abstract)

Chen HW (2001) Correlation analysis on bacteriological indexes and environmental parameters for surface water of Sanggou Bay. Mar Environ Sci 20:29-33 (in Chinese with English abstract)

- Duarte P, Meneses R, Hawkins AJS, Zhu M, Fang J, Grant J (2003) Mathematical modelling to assess the carrying capacity for multi-species culture within coastal waters. Ecol Model 168:109-143

Fan X, Wei H (2010) Modeling studies on vertical structure of tidal current in a typically coastal raft-culture area. Prog Fish Sci 31:78-84 (in Chinese with English abstract)

Fang JG, Sun HL, Yan JP, Kuang SH, Li F, Newkirk GF, Grant J (1996a) Polyculture of scallop Chlamys farreri and kelp Laminaria japonica in Sungo Bay. Chin J Oceanol Limnol 14:322-329
Fang JG, Kuang SH, Sun HL, Li F, Zhang AJ, Wang XZ, Tang TY (1996b) Mariculture status and optimizing measurements for the culture of scallop Chlamys farreri and kelp Laminaria japonica in Sungou Bay. Mar Fish Res 17:95-102 (in Chinese with English abstract)

FAO (Food and Agriculture Organization of the United Nations) (2010) The state of world fisheries and aquaculture 2010. Fisheries and Aquaculture Department, FAO, Rome

Fei XG (2004) Solving the coastal eutrophication problem by large scale seaweed cultivation. Hydrobiologia 512: 145-151

Forrest BM, Keeley NB, Hopkins GA, Webb SC, Clement DM (2009) Bivalve aquaculture in estuaries: review and synthesis of oyster cultivation effects. Aquaculture 298: $1-15$

> Fu MZ, Pu XM, Wang ZL, Liu XJ (2013) Integrated assessment of mariculture ecosystem health in Sanggou Bay. Acta Ecol Sin 33:238-316 (in Chinese with English abstract)

Gordon DC, Boudreau PR, Mann KH, Ong JE and others (1996) LOICZ biogeochemical modeling guidelines. LOICZ Reports and Studies (5). Land-Ocean Interactions in the Coastal Zone, Texel

Grant J, Bacher C (2001) A numerical model of flow modification induced by suspended aquaculture in a Chinese Bay. Can J Fish Aquat Sci 58:1-9

Grasshoff K, Kremling K, Ehrhardt M (1999) Methods of seawater analysis. In: Hansen HP, Koroleff F (eds) Determination of nutrients. Wiley-VCH, Weinheim, p 159-228

Guo ZR, Huang L, Liu HT, Yuan XJ (2008) The estimation of submarine inputs of groundwater to a coastal bay using radium isotopes. Acta Geosci Sin 29:647-652 (in Chinese with English abstract)

Han LJ, Zhu YM, Liu SM, Zhang J, Li RH (2013) Nutrients of atmospheric wet deposition from the Qianliyan Island of the Yellow Sea. China Environ Sci 33:1174-1184 (in Chinese with English abstract)

Hao LH, Sun PX, Hao JM, Du BB, Zhang XJ, Xu YS, Bi JH (2012) The spatial and temporal distribution of chlorophyll-a and its influencing factors in Sanggou Bay. Ecol Environ Sci 21:338-345 (in Chinese with English abstract)

> Heggie K, Savage C (2009) Nitrogen yields from New Zealand coastal catchments to receiving estuaries. N Z J Mar Freshw Res 43:1039-1052

> Herbeck LS, Unger D, Wu Y, Jennerjahn TC (2013) Effluent, nutrient and organic matter export from shrimp and fish ponds causing eutrophication in coastal and back-reef waters of NE Hainan, Tropical China. Cont Shelf Res 57: 92-104

Hyun JH, Kim SH, Mok JS, Lee JS, An SU, Lee WC (2013) Impacts of long-line aquaculture of Pacific oysters (Crassostrea gigas) on sulfate reduction and diffusive nutrient flux in the coastal sediments of JinhaeTongyeong, Korea. Mar Pollut Bull 74:187-198

Jackson C, Preston N, Thompson PJ, Burford M (2003) Nitrogen budget and effluent nitrogen components at an intensive shrimp farm. Aquaculture 218:397-411

Jennerjahn TC, Nasir B, Pohlenga I (2009) Spatio-temporal variation of dissolved inorganic nutrients related to hydrodynamics and land use in the mangrove-fringed Segara Anakan Lagoon, Java, Indonesia. Reg Environ Change 9:259-274

Jiang ZJ, Fang JG, Zhang JH, Mao YZ, Wang W (2007) Forms and bioavailability of phosphorus in surface sedi- 
ments from Sungo Bay. Huan Jing Ke Xue (Environ Sci) 28:2783-2788 (in Chinese with English abstract)

Justić D, Rabalais NN, Turner RE, Dortch Q (1995) Changes in nutrient structure of river-dominated coastal waters: stoichiometric nutrient balance and its consequences. Estuar Coast Shelf Sci 40:339-356

Kuang S, Fang J, Sun H, Li F (1996) Seston dynamics in Sanggou Bay. Mar Fish Res 17:60-67 (in Chinese with English abstract)

Liu SM, Zhang J, Chen HT, Zhang GS (2005) Factors influencing nutrient dynamics in the eutrophic Jiaozhou Bay, North China. Prog Oceanogr 66:66-85

Liu SM, Li XN, Zhang J, Wei H, Ren JL, Zhang GL (2007) Nutrient dynamics in Jiaozhou Bay. Water Air Soil Pollut Focus 7:625-643

Liu SM, Hong GH, Zhang J, Ye XW, Jiang XL (2009) Nutrient budgets for large Chinese estuaries. Biogeosciences 6:2245-2263

Liu SM, Li RH, Zhang GL, Wang DR and others (2011) The impact of anthropogenic activities on nutrient cycling dynamics in the tropical Wenchanghe and Wenjiaohe Estuary and Lagoon system in East Hainan, China. Mar Chem 125:49-68

Mao YZ, Zhou Y, Yang HS, Wang RC (2006) Seasonal variation in metabolism of cultured Pacific oyster, Crassostrea gigas, in Sanggou Bay, China. Aquaculture 253:322-333

Marinho-Soriano E, Nunes SO, Carneiro MAA, Pereira DC (2009) Nutrients' removal from aquaculture wastewater using the macroalgae Gracilaria birdiae. Biomass Bioenergy 33:327-331

Moore WS (1996) Large groundwater inputs to coastal waters revealed by ${ }^{226}$ Ra enrichments. Nature 380:612-614

> Neori A, Chopin T, Troell M, Buschmann AH and others (2004) Integrated aquaculture: rationale, evolution and state of the art emphasizing seaweed biofiltration in modern mariculture. Aquaculture 231:361-391

Newell RIE (2004) Ecosystem influences of natural and cultivated populations of suspension-feeding bivalve molluscs: a review. J Shellfish Res 23:51-61

> Newell RIE, Koch EW (2004) Modeling seagrass density and distribution in response to changes in turbidity stemming from bivalve filtration and seagrass sediment stabilization. Estuaries 27:793-806

Ning Z, Liu S, Zhang G, Ning X and others (2016) Impacts of an integrated multi-trophic aquaculture system on benthic nutrient fluxes: a case study in Sanggou Bay, China. Aquacult Environ Interact 8:221-232

Nobre AM, Robertson-Andersson D, Neori A, Sankar K (2010) Ecological-economic assessment of aquaculture options: comparison between abalone monoculture and integrated multi-trophic aquaculture of abalone seaweeds. Aquaculture 306:116-126

> Nunes JP, Ferreira JG, Gazeau F, Lencart-Silva J, Zhang XL, Zhu MY, Fang JG (2003) A model for sustainable management of shellfish polyculture in coastal bays. Aquaculture 219:257-277

Olli K, Clarke A, Danielsson Å, Aigars J, Conley D, Tamminen $\mathrm{T}$ (2008) Diatom stratigraphy and long-term dissolved silica concentrations in the Baltic Sea. J Mar Syst 73:284-299

> Pietros JM, Rice MA (2003) The impacts of aquacultured oysters, Crassotrea virginica (Gmelin, 1791) on water column nitrogen and sedimentation: results of a mesocosm study. Aquaculture 220:407-422

Savchuk OP (2005) Resolving the Baltic Sea into seven sub- basins: $\mathrm{N}$ and P budgets for 1991-1999. J Mar Syst 56: $1-15$

Schneider O, Sereti V, Eding EH, Verreth JAJ (2005) Analysis of nutrient flows in integrated intensive aquaculture systems. Aquacult Eng 32:379-401

Shen ZL (2002) Long-term changes in nutrient structure and its influences on ecology and environment in Jiaozhou Bay. Oceanol Limnol Sin 33:322-331 (in Chinese with English abstract)

Shi J, Wei H, Zhang L, Yuan Y, Fang JG, Zhang JH (2011a) A physical-biological coupled aquaculture model for a suspended aquaculture area of China. Aquaculture 318: 412-424

Shi HH, Fang GH, Hu L, Zheng W (2011b) Analysis on response of pelagic ecosystem to kelp mariculture within coastal waters. J Waterway Harbor 32:213-218

Shpigel M (2005) Bivalves as biofilters and valuable byproducts in land-based aquaculture systems. In: Dame $\mathrm{RF}$, Olenin $\mathrm{S}$ (eds) The comparative roles of suspension feeders in ecosystems. Springer-Verlag, Dordrecht, p 183-197

Smaal A, van Stralen M, Schuiling E (2001) The interaction between shellfish culture and ecosystem processes. Can J Fish Aquat Sci 58:991-1002

Smith SV, Swaney DP, Talaue-McManus L, Bartley JD and others (2003) Humans, hydrology, and the distribution of inorganic nutrient loading to the ocean. Bioscience 53: 235-245

Song HJ, Li RX, Wang ZL, Zhang XL, Liu P (2007) Interannual variations in phytoplankton diversity in the Sanggou Bay. Adv Mar Sci 25:332-339 (in Chinese with English abstract)

Song XL, Yang Q, Sun Y, Yin H, Jiang SL (2012) Study of sedimentary section records of organic matter in Sanggou Bay over the last 200 years. Acta Oceanol Sin 34: 120-126 (in Chinese with English abstract)

Song YL, Cui Y, Sun Y, Fang JG, Sun HL, Kuang SH (1996) Study on nutrient state and influencing factors in Sanggou Bay. Mar Fisher Res 17(2):41-51 (in Chinese with English abstract)

Stadmark J, Conley DJ (2011) Mussel farming as a nutrient reduction measure in the Baltic Sea: consideration of nutrient biogeochemical cycles. Mar Pollut Bull 62:1385-1388

Sun PX, Zhang ZH, Hao LH, Wang B and others (2007) Analysis of nutrient distributions and potential eutrophication in seawater of the Sanggou Bay. Adv Mar Sci 25: 436-445 (in Chinese with English abstract)

Sun S, Liu SM, Ren JL, Zhang JH, Jiang ZJ (2010) Distribution features of nutrients and flux across the sedimentwater interface in the Sanggou Bay. Acta Oceanol Sin 32: 108-117 (in Chinese with English abstract)

Sun S, Li CL, Zhang GT, Sun XX, Yang B (2011) Long-term changes in the zooplankton community in the Jiaozhou Bay. Oceanol Limnol Sin 42:625-631 (in Chinese with English abstract)

Tang QS, Fang JG, Zhang JH, Jiang ZJ, Liu HM (2013) Impacts of multiple stressors on coastal ocean ecosystems and integrated multi-trophic aquaculture. Prog Fish Sci 34:1-11 (in Chinese with English abstract)

> Tango PJ, Magnien R, Butler W, Luckett C, Luckenbach M, Lacouture R, Poukish C (2005) Impacts and potential effects due to Prorocentrum minimum blooms in Chesapeake Bay. Harmful Algae 4:525-531

The People's Republic of China Ministry of Agriculture Fisheries Bureau (2013) China Fishery Statistical Yearbook. 
China Agriculture Press, Beijing (in Chinese)

Troell M, Joyce A, Chopin T, Neori A, Buschmann AH, Fang JG (2009) Ecological engineering in aquaculture-potential for integrated multi-trophic aquaculture (IMTA) in marine offshore systems. Aquaculture 297:1-9

Turner RE, Qureshi N, Rabalais NN, Dortch Q, Justi D, Shaw RF, Cope J (1998) Fluctuating silicate: nitrate ratios and coastal plankton food webs. Proc Natl Acad Sci USA 95:13048-13051

Wall CC, Peterson BJ, Gobler CJ (2008) Facilitation of seagrass Zostera marina productivity by suspension-feeding bivalves. Mar Ecol Prog Ser 357:165-174

Wan L (2012) Effect of shellfish farming on nutrient salts of seawater in Sanggou Bay in spring. Environ Sci Manag 2012(6):62-64 (in Chinese with English abstract)

Wang XL, Du JZ, Ji T, Wen TY, Liu SM, Zhang J (2014) An estimation of nutrient fluxes via submarine groundwater discharge into the Sanggou Bay-a typical multi-species culture ecosystem in China. Mar Chem 167:113-122

> Wang ZH, Zhao JG, Zhang YJ, Cao Y (2009) Phytoplankton community structure and environmental parameters in aquaculture areas of Daya Bay, South China Sea. J Environ Sci (China) 21:1268-1275

Wei H, Zhao L, Yuan Y, Shi J, Fan X (2010) Study of hydrodynamics and its impact on mariculture carrying capacity of Sanggou Bay: observation and modeling. Prog Fish Sci 31:65-71 (in Chinese with English abstract)

> Wu H, Peng RH, Yang Y, He L, Wang WQ, Zheng TL, Lin $\mathrm{GH}$ (2014) Mariculture pond influence on mangrove areas in south China: significantly larger nitrogen and phosphorus loadings from sediment wash-out than from tidal water exchange. Aquaculture 426-427:204-212

Yang YF, Li CH, Nie XP, Tang DL, Chuang EK (2005) Development of mariculture and its impacts in Chinese coastal waters. Rev Fish Biol Fish 14:1-10

Yu HY, Bao LJ, Wong CS, Hu Y, Zeng EY (2012) Sedimentary loadings and ecological significance of polycyclic aromatic hydrocarbons in a typical mariculture zone of South China. J Environ Monit 14:2685-2691

Yuan XT, Zhang MJ, Liang YB, Liu D, Guan DM (2010) Selfpollutant loading from a suspension aquaculture system

Editorial responsibility: Sebastien Lefebvre (Guest Editor), Wimereux, France of Japanese scallop (Patimopecten yessoensis) in the Changhai sea area, Northern Yellow Sea of China. Aquaculture 304:79-87

Zeng DY, Huang DJ, Qiao XD, He YQ, Zhang T (2015) Effect of suspended kelp culture on water exchange as estimated by in situ current measurement in Sanggou Bay, China. J Mar Syst 149:14-24

Zhang JH, Hansen PK, Fang JG, Wang W, Jiang ZJ (2009) Assessment of the local environmental impact of intensive marine shellfish and seaweed farming - application of the MOM system in the Sungo Bay, China. Aquaculture 287:304-310

Zhang JH, Shang DR, Wang W, Jiang ZJ, Xue SY, Fang JG (2010) The potential for utilizing fouling macroalgae as feed for abalone Haliotis discus hannai. Aquacult Res 41: 1770-1777

Zhang JH, Wang W, Hang TT, Liu DH and others (2012) The distributions of dissolved nutrients in spring of Sungo Bay and potential reason of outbreak of red tide. J Fish China 36:132-138 (in Chinese with English abstract)

Zhang JH, Fang JG, Tang QS, Ren LH (2013) Carbon sequestration rate of the scallop Chlamys farreri cultivated in different areas of Sanggou Bay. Prog Fish Sci 34: 12-16 (in Chinese with English abstract)

Zhang LH, Zhang XL, Li RX, Wang ZL and others (2005) Impact of scallop culture in dinoflagellate abundance in the Sanggou Bay. Adv Mar Sci 23:342-346 (in Chinese with English abstract)

Zhao J, Zhou SL, Sun Y, Fang JG (1996) Research on Sanggou bay aquaculture hydro-environment. Mar Fish Res 17:68-79

Zhou Y, Mao YZ, Yang HS, He YZ, Zhang FS (2002a) Clearance rate, ingestion rate and absorption efficiency of the scallop Chlamys farreri measured by in situ biodeposition method. Acta Ecol Sin 22:1455-1462 (in Chinese with English abstract)

Zhou Y, Yang HS, Liu SL, He YZ, Zhang FS (2002b) Chemical composition and net organic production of cultivated and fouling organisms in Sishili Bay and their ecological effects. J Fish China 26:21-27 (in Chinese with English abstract)

Submitted: June 1, 2015; Accepted: March 7, 2016

Proofs received from author(s): March 24, 2016 